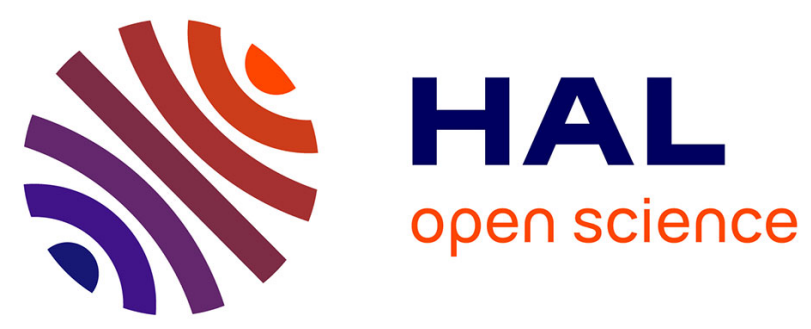

\title{
Transition from subduction to collision recorded in the Pan-African arc complexes (Mali to Ghana)
}

Stéphane Guillot, Yao Agbossoumondé, Jerôme Bascou, Julien Berger, Guillaume Duclaux, Nadège Hilairet, René-Pierre Ménot, Stéphane Schwartz

\section{- To cite this version:}

Stéphane Guillot, Yao Agbossoumondé, Jerôme Bascou, Julien Berger, Guillaume Duclaux, et al.. Transition from subduction to collision recorded in the Pan-African arc complexes (Mali to Ghana). Precambrian Research, 2019, 320, pp.261-280. 10.1016/j.precamres.2018.11.007 . hal-01938224

\author{
HAL Id: hal-01938224 \\ https://hal.uca.fr/hal-01938224
}

Submitted on 29 Oct 2021

HAL is a multi-disciplinary open access archive for the deposit and dissemination of scientific research documents, whether they are published or not. The documents may come from teaching and research institutions in France or abroad, or from public or private research centers.
L'archive ouverte pluridisciplinaire HAL, est destinée au dépôt et à la diffusion de documents scientifiques de niveau recherche, publiés ou non, émanant des établissements d'enseignement et de recherche français ou étrangers, des laboratoires publics ou privés.

\section{(1) (1) $\$$}

Distributed under a Creative Commons Attribution - NonCommercial - NoDerivatives| 4.0 


\title{
Transition from subduction to collision recorded in the Pan-African arc complexes (Mali to Ghana)
}

aStéphane Guillot, ${ }^{b}$ Yao Agbossoumondé, c Jérôme Bascou, d Julien Berger, ${ }^{\mathrm{e}}$ Guillaume Duclaux, ${ }^{\mathrm{f}}$ Nadège Hilairet, ${ }^{\mathrm{c}}$ René-Pierre Ménot, ${ }^{\text {aS }}$ téphane Schwartz

aUniv. Grenoble Alpes, Univ. Savoie Mont-Blanc, CNRS, IRD, IFSTTAR, ISTerre, 38000 Grenoble, France.

bUniversité de Lomé, Faculté des Sciences, Département de Géologie, BP 1515 Lomé, Togo

'Université de Lyon, Université Jean Monnet, CNRS, IRD, UMR 6524, Laboratoire Magmas et Volcans, 42023 Saint-Etienne, France.

dUniversité Paul Sabatier, CNRS, IRD, Géosciences Environnement Toulouse (GET) 14, Avenue Edouard Belin 31400 Toulouse

'Université Côte d'Azur, Université Nice Sophia Antipolis, CNRS, OCA, IRD, Géoazur, 250 rue Albert Einstein, Sophia Antipolis 06560 Valbonne, France.

fUniversité de Lille, CNRS, INRA, ENSCL, UMR 8207 - UMET - Unité Matériaux et Transformations, F-59000 Lille, France.

\begin{abstract}
The $1000 \mathrm{~km}$-long suture zone of the Dahomeyide belt, exposed from Southeast Ghana to South Mali, corresponds to a narrow and lithologically diverse area with symptomatic coronitic HP granulitic massifs. Based on a review of published petrological, geochemical and geochronological data along the Dahomeyide belt we propose a global scenario for the closure of the Pharusian ocean between the West African craton (WAC) and the Benino-Nigerian shield during the end of the Neoproterozoic. The onset of a long-lived oceanic subduction by 800-780 Ma is recorded by early magmatism in the Amalaoulaou intra-oceanic arc in Mali, contemporary to the Gourma and Adrar des Iforas to the North, and in Brazil to the South. The first occurrence of tonalitic plutons dated at $720 \mathrm{Ma}$, and the development of a forearc system around 650 Ma mark the onset of active margin subduction beneath the BeninoNigerain shield and its northward prolongation in Mali. Oceanic subduction beneath the active margin ended between 640 and 630 Ma with the onset of subduction of the WAC continental margin while subduction related magmatism continues till ca. $600 \mathrm{Ma}$ on the upper plate. During a short period between 620 and $610 \mathrm{Ma}$, the forearc system and the tip of the active continental margin were buried synchronously. The positive Bouguer anomaly observed to the East of the suture zone, in Benin, and not beneath the suture zone itself supports the occurrence of a massive mafic body at the base of the crust that could correspond to the underplated buried forearc. Ultimately, the exhumation and partial amphibolitization of the suture zone and a shift from a calc-alkaline magmatism to anatectic magmatism along with the onset of strike-slip faulting in the upper plate marks the transition from continental subduction to continental collision between 610 and $580 \mathrm{Ma}$. This work highlights the importance of the Pharusian suture zone s.l. To our knowledge, it represents a unique example
\end{abstract}


in the world in where the forearc system is buried and partly exhumed at the transition from subduction to collision.

\section{Introduction}

The Proterozoic-Phanerozoic transition constitutes a critical turning point in Earth's evolution in term of tectonic, magmatism, climate change and explosion of life (e.g. Veevers, 1995; Hoffman et al., 1998). Doblas et al. (2002) suggested that the amalgamation of the West African craton to the Pannotia (or Gondwana) supercontinent between 720 and 550 Ma gave rise to mantle insulation and a subsequent anorogenic "ring of fire" along the rim of this craton. It is then crucial to understand the mechanism and the timing for docking of the West African craton (WAC) to the Benino-Nigerian shield (BNS), i.e. part of the Saharan metacraton (Abdelsalam et al., 2002). Along the Eastern margin of the WAC, the Pan-African suture zone can be followed from northeast Brazil to Mali and Algeria and along the Dahomeyide belt from SE Ghana to Mali (Fig. 1a) (Trompette, 2000; Ganade de Araujo et al., 2014). The northern segment, also called the Pharusian belt has been thoroughly studied (e.g. Caby, 2003 for a complete review) and this author distinguishes three successive paleosubduction zones active between 790 and ca. $600 \mathrm{Ma}$. In northeast Brazil, the Proterozoic geology is more difficult to establish as a large Phanerozoic basin, the Parnaíba basin, largely covered the area. However, the striking correlation between the Kandi fault in Western Africa with Transbrasiliano lineament along with the occurrence of Neoproterozoic eclogites in Brazil, Togo and Gourma (Bernard-Griffiths et al., 1991; Caby et al., 1994; Agbossoumondé et al., 2001; Santos et al., 2009; 2015) clearly suggest that these segments correspond to the same suture zone (Caby, 1989; Castaing et al., 1993; Ganade de Araujo et al., 2014; 2016).

The central segment, the ca. $1000 \mathrm{~km}$ long Dahomeyide belt is well exposed from SE Ghana to Mali (Fig. 1a). In continuity with the large Pharusian belt, the Dahomeyide belt corresponds to a paleo-subduction zone underlined by garnet bearing mafic to ultramafic massifs (Ménot, 1980 and references therein; Ménot and Seddoh, 1985; Affaton et al., 1991; Attoh, 1998; Agbossoumondé et al., 2002; 2004). The Dahomeyide belt is usually subdivided in three main units from west to east (e.g., Affaton et al., 2000; Fig. 1b and Fig. 2): the western external units (Buem and Atacora), the suture zone, and the internal units that correspond to reactivation of the older BNS basement from ca.2.0 Ga to ca. 0.6 Ga, with emplacement of juvenile magmatic complexes and sediments during the Pan-African events (Table 1). According to the dominant westward vergence of the structures and the increasing of collisional imprints toward the east, the western and eastern units are related to the lower and upper plates, respectively, in a convergent plate scenario (Agbossoumondé et al., 2004 and references therein). The suture zone is well exposed from South-East Ghana to South Mali and corresponds to a narrow and lithologically diverse area marked by striking positive gravity and magnetic anomalies (El-Hadj Tidjani et al., 1997). Along this suture zone, deformed alkaline and calc-alkaline rocks, carbonatite and high- to ultrahigh-pressure (HPUHP) rocks and HP granulites occur (Attoh, 1998; Agbossoumondé et al., 2002, 2004; Attoh and Morgan, 2004; Duclaux et al., 2006; Attoh and Nude, 2008; Nude et al., 2009; Berger et al., 2011; Ganade de Araujo, 2014). If the presence of HP-UHP rocks in the Lato massif in Togo and in the Gourma massif in Mali clearly indicate the continental subduction of the eastern margin of the WAC by 620-610 Ma (Agbossoumondé et al., 2002; Caby et al., 2008; Ganade de Araujo, 2014) (Table1). The significance of other garnet bearing mafic massifs within the suture zone remain more elusive. Some are recognized as the root of a Neoproterozoic intra-oceanic arc affected by crustal thickening during magmatic maturation 
(e.g. Amaloulaou: Berger et al., 2011), other as a continental arc involved in the Pan-African continental subduction (e.g. Kabyé: Duclaux et al., 2006), or as post-orogenic massif (e.g. Djabatoré: Ménot and Seddoh, 1981; Attoh, 1998). Following a review of the main petrological and geochemical characteristics, metamorphic and geochronological evolution and tectonic observations, we propose that these mafic massifs correspond to the Neoproterozoic arc developed close to, or at the western margin of the Benino-Nigerian shield (upper plate) and partly amalgamated into the lower plate during the continental subduction of the margin of the West African craton, 620-610 Ma ago.

\section{Geological setting}

In the northern part of the Dahomeyides, the Amalaoulaou and the Kabyé massifs are well preserved and exposed (Fig. 1b). Both correspond to a tectonic complex composed of ultramafic to mafic units (UM-M) preserving different composition and metamorphic records, westward thrusting over the Neoproterozoic metasedimentary rocks and Paleoproterozoic orthogneisses of the WAC passive margin (Buscail and Caby, 2005; Duclaux et al., 2006; Agbossoumondé et al., 2007). The UM-M Amalaoulaou massif is composed from bottom to top with a serpentinite sole unit, an epidote-amphibolite unit, a granulitic garnet metagabbro unit containing spinel-garnet pyroxenite dykes, both retrogressed in HT amphibolite conditions, and an uppermost quartz-gabbro unit. The whole pile is folded along NE open to tight recumbent folds (Berger et al., 2011). The authors recalculated the U-Pb age on zircon of de la Boisse (1979) and proposed that the mafic magmatism onset at $793 \pm 4 \mathrm{Ma}$ followed with subsequent pulses of magmatism until $660 \mathrm{Ma}$, and final exhumation and cooling during the main Pan-African collision event between 620 and $580 \mathrm{Ma}$ (available geochronological data are summarized in Table 2). Dating of coesite eclogites in the Gourma belt, nearby Amalaoulaou yielded $623 \pm 3 \mathrm{Ma}$ (Sm-Nd on minerals, Jahn et al., 2001) and $611 \pm 4 \mathrm{Ma}$ (U$\mathrm{Pb}$ zircon; Ganade de Araujo et al., 2014).

The Dérouvarou massif outcrops in North-West Benin (Fig. 1), but it has not been investigated so far and few data are available. Aicard (1957) reported mafic granulites similar to those observed in the Kabyé massif metamorphosed at $615 \pm 6 \mathrm{Ma}$ (unpublished whole rock $\mathrm{Rb}-\mathrm{Sr}$ isochron age cited in Affaton et al., 2000).

The Kabyé massif is more monoclinal, dipping $30^{\circ}$ toward the east (Fig. 2) and striking in the north-south direction. Internal north-south thrusting shear zones, dipping east, split the massif in two main units (Duclaux et al., 2006; Tairou and Affaton, 2013). A granulitic gneiss interpreted as a felsic magmatic rock was poorly dated at about $640 \mathrm{Ma}$ (Bernard-Griffith et al., 1991), while muscovites from the Kara quartzites, just below the Kabyé massif were dated by $\mathrm{Ar} / \mathrm{Ar}$ at $633.8 \pm 0.5 \mathrm{Ma}$ (Attoh et al., 1997). Tonalites in the upper Kabyé unit are dated at $623 \pm 5 \mathrm{Ma}$ (Ganade, pers comm.). Granulitic peak of metamorphism is dated by Affaton et al. (2000) at $612 \pm 0.8 \mathrm{Ma}$ (U-Pb zircon).. The lower unit is dominated by garnet-bearing metapyroxenites lenses within strongly foliated garnet-bearing metagabbros while the upper unit consists of garnet-free metapyroxenites, metanorite and metadiorite crosscut by kyanitegarnet-bearing felsic dykelets and Al-rich felsic rocks. Thrusting toward the west under amphibolitic facies conditions is constrained by $\mathrm{Ar} / \mathrm{Ar}$ between 600 and $580 \mathrm{Ma}$ (BernardGriffith et al., 1991; Attoh et al., 1997).

Southward, the Djabatoré massif (Fig. 1) has only been briefly studied (Ménot and Seddoh, 1981; Duclaux, 2003). It is built up by layered metacumulates including troctolites, grabbronorites and gabbros compositions together with metagabbros and metadolerites as dykes and pods. They preserve striking igneous features although these rocks were 
equilibrated under granulite facies conditions and subsequently partially retrogressed to amphibolite facies. The contacts between the Djabatore massif and the amphibole-biotite gneiss country rocks are generally tectonic but intrusive contacts have been locally observed. For present, the Djabatoré massif has not been dated but field data argue for an Pan-African age.

At the SW edge of Togo, the Agou massif (Fig. 1) corresponds, in map view, to more or less circular zoned massif made of metagabbronorites \pm garnet at the core surrounded by garnet amphibolites and amphibolites. All these rocks are intrusive within the surrounding migmatitic gneisses (Fig. 1b). This massif has been initially interpreted as representing a latePan-African intrusion as it cuts across the migmatites (e.g. Agbossoumondé et al., 2004). But it has been shown that part of the migmatites and associated gneisses in the Dahomeyide suture zone represent pre-Neoproterozoic fragments of the WAC passive margin corresponding to the ca. $2.0 \mathrm{Ga}$ Paleoproterozoic tectono-metamorphic event described by Agbossoumondé et al. (2007 and references therein) and Attoh et al. (2013). The contacts between the UM-M units (with or without garnet) of the Agou massif are tectonic with an amphibolitic foliation oriented $\mathrm{N} 165^{\circ}$ to $\mathrm{N} 20^{\circ}$ dipping 55 to $80^{\circ}$ toward the east, similar to the surrounding gneisses (Agbossoumondé et al., 2004) confirming that both massifs were involved in the Pan-African collision and do not represent late Pan-African intrusives. Moreover, amphibolite facies recrystallisation events have been dated at ca 600-580 Ma (598 $\pm 12 \mathrm{Ma}$; whole rock Rb-Sr Bernard-Griffiths et al., 1991; $587 \pm 4 \mathrm{Ma}$ and $582 \pm 2 \mathrm{Ma}$; ArAr Attoh et al., 1997) confirming the Pan-African, rather than late-Pan-African affinity of these massifs.

More to the East, garnet-bearing amphibolites have been observed in the Notse area (SE Togo, Fig. 1b). Those rocks outcrop as lenses embedded within the surrounding migmatites. Migmatisation is dated at $606 \pm 5 \mathrm{Ma}$ (U-Pb on Zircon, Adissin, 2014).

In SE Ghana (Shai Hills, Fig. 1b), Attoh (1998) cited in Attoh and Morgan (2004) described eclogite retrogressed under HP granulitic facies. But in the original paper, Attoh (1998) shows that the garnet-diposide assemblage is coronitic and developed at the expense of orthopyroxene + plagioclase under granulitic facies conditions. Similarly, Hirdes and Davis

(2002) described strongly foliated garnet bearing amphibolite locally preserving clinopyroxene and rutile symptomatic of HP granulitic metamorphism. Geochronological studies also provide well-constrained information on the HP mafic granulites in SE Ghana. Agyei et al. (1987) reported a $\mathrm{Rb}-\mathrm{Sr}$ whole rock isochron and $\mathrm{K}-\mathrm{Ar}$ mineral ages for amphibolitic gneisses comprised between 615 and $590 \mathrm{Ma}$. Attoh et al. (1991) reported U-Pb zircon age of $612 \pm 0.8 \mathrm{Ma}$ on mafic granulites while Hirdes and Davis (2002) reported U-Pb zircon age on similar granulites at $603 \pm 5 \mathrm{Ma}$. U-Pb analyses of zircon fractions from associated orthogneisses yielded strongly discordant ages which suggest $\mathrm{Pb}$ loss at ca. $560 \mathrm{Ma}$ following crystallization of a granitic protolith at ca. $650 \mathrm{Ma}$ (Attoh et al., 1991). Similarly, Hirdes and Davis (2002) reported upper concordia intercept ages at $689+127 /-61 \mathrm{Ma}$ that roughly correspond to the same crystallization age. Cooling under amphibolite facies is dated at $584 \pm 5 \mathrm{Ma}$.

\section{Petrology}

The petrology of some massifs (e.g. Amalaoulaou, Kabyé, Djabatoré and Agou) have been thoroughly investigated, while others have been less or not investigated at all. In order to be compared here, we only describe the petrology of the mafic rocks in the well-studied massifs. Available lithologies are summarized in Table 3.

Metagabbro is the dominant lithology in the Amalaoulaou complex (Berger et al., 2009; 
2011). These metagabbros consist of plagioclase-clinopyroxene (Cpx I) \pm orthopyroxene \pm large garnet porphyroblasts \pm brown amphibole (Fig. 3a). In detail several generations of clinopyroxene have been recognized on the basis of texture and mineral chemistry (Berger et al., 2011): clinopyroxene I associated to plagioclase, orthopyroxene and rare hastingsite is inherited from the magmatic stage; clinopyroxene II associated to garnet, rutile and localized trondjhemitic leucosomes forms rounded inclusions within garnet porphyroblasts; clinopyroxene III is associated with the growth of brown amphibole and ilmenite and a distributed foliation locally associated to $\mathrm{cm}$-thick mylonite bands. Spinel and garnet pyroxenite dykes/sills are common within the metagabbro unit. In the mafic host rock, the contact is marked by the development of garnet-rich domain and partial melting (Fig. $3 \mathrm{f}$ in Berger et al., 2011). Evidence for late, LT amphibolitic facies deformation and retrogression is given by the local development of green magnesio-hornblende and chlorite and by the complete replacement of plagioclase by late low temperature assemblage (epidote-albitewhite mica \pm pyrite \pm barite). The two-pyroxenes + plagioclase assemblage is magmatic (Berger et al., 2011) and formed around $950{ }^{\circ} \mathrm{C}$ and $10 \mathrm{kbar}$ (Berger et al., 2011) while the garnet-clinopyroxene II paragenesis, locally associated with HP mafic migmatites, is symptomatic of HP granulitic facies conditions. This secondary granulitic overprint developed at higher pressure (10-12 kbar) but in a large temperature interval bracketed between 800 and $1000{ }^{\circ} \mathrm{C}$; the higher temperature characterizing the contact zone with pyroxenite intrusions. Secondary brown amphibole and pervasive deformation occurred around $800{ }^{\circ} \mathrm{C}$ at $7-10 \mathrm{kbar}$ and resulted from partial exhumation of the metagabbroic unit. Coronitic garnet surrounding spinel in pyroxenite developed at similar conditions. It is followed by retrogression under amphibolite facies conditions at about 6-9 kbar and $570-520^{\circ} \mathrm{C}$. The upper quartz gabbro unit presents a magmatic assemblage dominated by clinopyroxene, plagioclase and quartz and locally affected by secondary metamorphic recrystallisations and deformation. Green hornblende and chlorite grew along the rims of igneous clinopyroxene while plagioclase is totally retrogressed into fine-grained albite-epidote intergrowth. These recrystallisations can be ascribed to LT amphibolite or even greenschist conditions.

The Kabyé massif (Fig. 1b) has been built up with mantle derived mafic magmas. Most of mafic rocks are cumulate metagabbros and metapyroxenites with preserved igneous textures in spite of granulite facies metamorphism. The primary, magmatic, layering of cumulates may be still recognized (Duclaux et al., 2006). Two main rock types have been identified within the layered series: (i) ubiquitous layered meso- to leucocratic metagabbros; (ii) melanocratic garnet-bearing and garnet-free metaclinopyroxenites that are interlayered and intrusive within the metagabbro banded series. The lower unit is composed of garnetbearing granulites and garnet-bearing clinopyroxenites. Clinopyroxenites occur as less foliated layers or elongated xenoliths within the garnet-bearing metagabbros. The garnetbearing granulites, interpreted as metagabbros (Duclaux et al., 2006), are characterised by garnet-clinopyroxene-plagioclase \pm orthopyroxene with subordinate rutile and quartz. Garnet appears as coronas around clinopyroxenes (Fig. 3b). In the lower unit, the P-T conditions of the magmatic stage cannot be estimated due to a strong granulitic overprint. This latter is estimated to peak at $18 \pm 2.5 \mathrm{kbar}$ and $840 \pm 20^{\circ} \mathrm{C}$ followed by an amphibolitic retrogression from $9 \pm 2 \mathrm{kbar}$ and $800-750{ }^{\circ} \mathrm{C}$ to $3-5 \mathrm{kbar}$ and $700-650^{\circ} \mathrm{C}$ (Hilairet, 2004).

The upper unit is composed of dominant garnet-free orthopyroxene-clinopyroxeneplagioclase \pm rutile \pm quartz granulites and minor garnet-bearing granulites and garnet-free clinopyroxenites. The later also occur as less foliated layers or elongated xenoliths within the granulites. As underlined by Duclaux et al. (2006), most of the granulites in the upper unit display a striking layering, which is marked both by a thin millimetric metamorphic banding with alternation of plagioclase and ferromagnesian-rich layers, and by a thicker centimetre to decimetre compositional layering with the succession of dominant clinopyroxene-garnet- 
plagioclase bearing facies and subordinate orthopyroxene-clinopyroxene-plagioclase (garnetfree) paragenesis. Such a feature probably reflects an inherited compositional magmatic layering which is overlaid by a secondary subconcordant regional metamorphic foliation. Deformation features are seen as clinopyroxene and garnet porphyroclasts together with a mineral stretching lineation underlined by clinopyroxene and garnet alignment. The preserved orthopyroxene-plagioclase magmatic paragenesis crystallised at 6-7 kbar and $950{ }^{\circ} \mathrm{C}$ followed by the granulitic imprint estimated at $12 \pm 1.5 \mathrm{kbar}$ and $800{ }^{\circ} \mathrm{C}$ (Hilairet, 2004). The upper unit also recorded the same amphibolitic retrogression suggesting that both units were tectonically in contact at that time.

The Dérouvarou massif (Fig. 1b) has been investigated by Aicard (1957). He described metagabbros similar to those described elsewhere in the Amalaoulaou and Kabyé massifs with a granulitic imprint (garnet growth) and secondary amphibolitization at their bases. Moreover, the cross-section of the Dérouvarou massif proposed by Caby (1987) is similar to that of the Kabyé massif with a massive mafic unit thrusting westward over the WAC. The metamorphic conditions are unknown but considering the granulitic paragenesis, we assume that they are similar or close to those recorded by the nearby granulitic massifs.

The Djabatore massif is the best-preserved UM-M complex from the metamorphic overprint and the cumulates pile displays a spectacular magmatic layering marked by the succession of olivine-gabbros, troctolites, gabbros and gabbro-norites, currently associated with a strong mineral lamination (Ménot and Seddoh, 1980; Duclaux, 2003). In the Djabatoré massif, metagabbros are dominant with a magmatic assemblage composed of clinopyroxene (diopside) - plagioclase $\left(\mathrm{An}_{60-68}\right) \pm$ orthopyroxene $\left(\mathrm{En}_{64-71}\right) \pm$ spinel \pm ilmenite and rare olivines (Ménot and Seddoh, 1980; Duclaux, 2003). Olivines are generally replaced by secondary orthopyroxenes and oxides symptomatic of magmatic cooling (Fig. 3c). The crystallization conditions are estimated at $9 \pm 1 \mathrm{kbar}$ for $900{ }^{\circ} \mathrm{C} \pm 50{ }^{\circ} \mathrm{C}$ (Duclaux, 2003). The only evidences of retromorphic imprint are the recrystallisation of a rim of tschermakitic amphibole, and of spinel, and of pargasite + corundum + Ca-poor amphiboles (3-4 kbar, 600 ${ }^{\circ} \mathrm{C}$ ) and the later local replacement of the plagioclase by epidote.

The Agou massif has been already investigated by Attoh (1998) and Agbossoumondé et al. (2004). As the other massifs, the metababbro paragenesis consists of a primary paragenesis with clinopyroxene - plagioclase $\left(\mathrm{An}_{50-60}\right)$ - orthopyroxene \pm ilmenite equilibrated at $8 \pm 1$ kbar for a $\mathrm{T}>850{ }^{\circ} \mathrm{C}$ (Agbossoumondé et al. 2004). This assemblage is transformed to a secondary assemblage crystallising as a simple corona along the orthopyroxene-plagioclase boundaries and formed by intergrowths of quartz and radial clinopyroxene II. Primary plagioclase also recrystallises as a granoblastic mosaic of clouded secondary plagioclases (An 30-40) charged with inclusions of sillimanite, orthopyroxene and magnetite. Locally, the primary assemblage is surrounded by complex coronas with the development of clinopyroxene II around the orthopyroxene and garnet in contact with plagioclase (Fig. 4d), and secondary quartz. This granulitisation occurred at about $10 \mathrm{kbar}$ and $770{ }^{\circ} \mathrm{C}$ (Agbossoumondé et al. 2004). Primary ilmenite is also replaced by rutile. Three successive stages of retrogression are then observed from hornblende-granulite facies $\left(700-750{ }^{\circ} \mathrm{C}, 9\right.$ kbar) to amphibolite facies $\left(700{ }^{\circ} \mathrm{C}, 6-7 \mathrm{kbar}\right)$ and finally greenschist facies conditions $(550$ $500{ }^{\circ} \mathrm{C}, 3-4 \mathrm{kbar}$ ) (Agbossoumondé et al. 2004).

Southward in Ghana, similar metagabbros (clinopyroxene-orthopyroxene-plagioclaseilmenite) with garnet-bearing coronas are described by Attoh (1998) in the Shai hills (Fig.1b). Sillimanite is locally associated with secondary plagioclase (Fig. 4e). Secondary amphibolitization is also observed. Attoh (1998) estimated that the initial magmatic orthopyroxene-plagioclase assemblage crystallised at about $9 \pm 1 \mathrm{kbar}$ and $900{ }^{\circ} \mathrm{C}$ while the coronitic metamorphic garnet-clinopyroxene assemblage crystallised at $14 \mathrm{kbar}$ for a temperature between 900 and $800{ }^{\circ} \mathrm{C}$. The retrogressed cooling path occurred from granulitic 
conditions $\left(9 \mathrm{kbar}\right.$ and $\left.800{ }^{\circ} \mathrm{C}\right)$, then amphibolitic conditions down to $5 \mathrm{kbar}$ and $550{ }^{\circ} \mathrm{C}$.

In SE Togo, in the Notsé massif, garnet-bearing amphibolites are described for the first time. Coarse-grain undeformed rock (TO211) is composed of garnet, clinopyroxene, plagioclase, amphibole, quartz and ilmenite (Fig. 3f). Garnets form large porphyroblasts surrounded by a rim of secondary plagioclase. Garnet cores are almandine rich $\left(\mathrm{Alm}_{58}\right)$ with a slight increase in Fe-content rimward (Alm60) correlated with Mg-content decrease ( $\operatorname{Prp}_{22}$ to 19). Clinopyroxenes are in textural equilibrium with garnet. They are low jadeite content (< $2 \%$ ), enriched in magnesium, iron and calcium, typical of augite. Primary plagioclases are homogeneous with low potassium content (0.12-0.24 wt $\left.\% \quad \mathrm{~K}_{2} \mathrm{O}\right)$ with an andesine composition. Secondary amphiboles developed at the expense of clinopyroxene. They show a typical hornblende composition. However, the enrichment in $\mathrm{FeO}(16$ to $17 \%)$ relative to $\mathrm{MgO}$ (11.15 to $12.22 \%$ ) indicates a pargasitic contribution, reflecting the transition from granulite facies to HT amphibolite facies conditions. Ilmenite is in textural equilibrium with both assemblages. The primary garnet-clinopyroxene-ilmenite-plagioclase-quartz assemblage cristallised at $6 \pm 1 \mathrm{kbar}$ and $850{ }^{\circ} \mathrm{C}$ while the secondary assemblage garnet-pargasite-quartzilmenite records a pressure increase up to $8 \mathrm{kbar} \pm 1.5 \mathrm{kbar}$ for a temperature of $660 \pm 60^{\circ} \mathrm{C}$ (Daoudene, 2005). Another sample (TO215) has been investigated and their mineralogical composition is similar to the previous one with coronitic reaction textures formed by garnet, clinopyroxene, amphibole, rutile, ilmenite, and to a lesser extent titanite, zoisite, plagioclase, quartz. Garnet is abundant and is surrounded by a rim of symplectite reaction, indicating garnet destabilisation during pressure and/or temperature conditions change. Garnets show a relatively homogeneous composition, $\left(\operatorname{Prp}_{32} ; \mathrm{Alm}_{38} ; \mathrm{Grs}_{30}\right)$ (Fig. 2a). As for the sample TO211 the clinopyroxene is destabilised into amphibole. Clinopyroxenes have a composition of diopside-augite. Their jadeitic content up to $14 \%$ indicates that it is still granulitic clinopyroxene, but at higher pressure than for TO211. The metamorphic peak is estimated at $11 \pm \mathrm{kbar}$ and $750 \pm 50^{\circ} \mathrm{C}$. The amphibole is pargasitic hornblende, rich in $\mathrm{MgO}$ with lower $\mathrm{FeO}$, compared to TO211. Plagioclase is calcium rich $\left(\mathrm{An}_{70}\right)$. Finally, rutile is early relative to ilmenite suggesting amphibolitic conditions of $6 \pm 1 \mathrm{kbar}$ and $660 \pm 60{ }^{\circ} \mathrm{C}$ (Daoudene, 2005).

\section{Geochemistry}

Here, we summarise and compare the available published geochemical data coming from the Amalaoulaou massif (Berger et al., 2011), the Kabyé massif (Duclaux et al., 2006), the Agou massif (Agbossoumondé et al., 2013); Djabatoré (Duclaux, 2003 and unpublished data) and from SE Ghana (Attoh and Morgan, 2004; Attoh and Smith, 2005). Geochemical data are presented in Table 4. As the geochemistry of the studied samples is quite comparable from one massif to another, we will make a common description. Geochemical data from West African complexes are compared to Andean plutonic rocks and Kohistan samples representing continental and oceanic arc rocks, respectively. Compiled data were extracted from the online GEOROC database (http://georoc.mpch-mainz.gwdg.de/georoc).

Most samples are characterised by low $\mathrm{SiO}_{2}$ contents $(<55 \mathrm{wt} \%)$ with high $\mathrm{MgO}$ (up to $15 \mathrm{wt} \%$ ) which is typical of ferromagnesian mineral cumulates (olivine, clinopyroxene and spinel) as evidenced by the high Cr content of these samples (up to $649 \mathrm{ppm}$ instead of 100 $200 \mathrm{ppm}$ for other samples). Pyroxenites have generally higher $\mathrm{CaO}(>12 \mathrm{wt} \%)$ and $\mathrm{MgO}(>$ $10 \mathrm{wt} \%$ ) and represent pyroxene cumulates instead of chilled melts or mantle pyroxenites.

The majority of the samples, whatever massifs, aligned along a basaltic to a trachy- 
andesitic trend with $\mathrm{SiO}_{2}$ ranging from 45 to $56.55 \mathrm{wt} \%$ and an alkaline content up to $5.95 \mathrm{wt}$ $\%$ (Fig. 4). Two samples from Agou and one from Kabyé and Amalaou are more differentiated and fall in the dacitic field.

In the TAS diagram (Fig. 4), basic samples from West African complexes are similar to both plutonic continental (Andes) and oceanic (Kohistan) arc rocks. A close look to intermediate samples $\left(\mathrm{SiO}_{2} \sim 55 \mathrm{wt} \%\right)$ reveals that three samples from Kabyé and one from Agou are more alkali-rich (due to higher K contents) and are thus more comparable to Andean arcs. The Amalaoulaou complex is similar to Kohistan arc rocks with its low alkali and especially $\mathrm{K}$ content (Fig. 4) except for one sample with $45 \% \mathrm{SiO}_{2}$ and $4.5 \mathrm{wt} \% \mathrm{Na}_{2} \mathrm{O}+\mathrm{K}_{2} \mathrm{O}$. The latter is an alkaline metabasalt found in the epidote-amphibolite metamorphic sole of the complex.

Primitive Mantle-normalised REE-diagrams for metabasalts and metagabbros samples show similar patterns for Amalaoulaou, Kabyé, Agou and SE Ghana (Fig. 5) suggesting a common source and similar magmatic evolution. All the samples are enriched ( 8 to more than 100 times the Primitive Mantle values) and display a LREE enriched pattern with $\mathrm{La}_{\mathrm{N}} / \mathrm{Yb}_{\mathrm{N}}=$ 3.5 and $\mathrm{La}_{\mathrm{N}} / \mathrm{Nd}_{\mathrm{N}}=1.43$, and no Eu anomaly. Absence of Eu anomaly suggests either that these rocks are not cumulative or the abundance of clinopyroxene and orthopyroxene having a negative $\mathrm{Eu}$ anomaly equilibrated the positive $\mathrm{Eu}$ anomaly due to the occurrence of plagioclase (Duclaux et al., 2006). Two samples from the Kabyé massif are more enriched than the average analysed sample suggesting either a similar source with a lower degree of partial melting, or more important contamination by a continental component. This second hypothesis can be ruled out as in the $\mathrm{Sr}$ vs $\mathrm{Nd}$ isotopic diagram these samples do not show any evidence of contamination (Fig. 7). REE patterns (Fig. 5) are fractionated $\left(\mathrm{Ce}_{\mathrm{N}} / \mathrm{Yb}_{\mathrm{N}} \sim\right.$ 10.0-18) with slight LREE enrichment $\left(\mathrm{Ce}_{\mathrm{N}} / \mathrm{Sm}_{\mathrm{N}} \sim 3-4\right)$ and HREE depletion $\left(\mathrm{Sm}_{\mathrm{N}} / \mathrm{Yb}_{\mathrm{N}} \sim\right.$ 3.4-4.9) that could be induced by a garnet residue in the melt source. These features are typical for magmas directly derived from mantle in a subduction related environment at depth greater than $90 \mathrm{~km}$ (e.g. Tatsumi, 1989). The Primitive Mantle-normalised REE-diagrams for Djabatoré are significantly different. They are all slightly enriched and present convex-like spectra, close to those of N-MORB. The positive anomaly in Eu is quite pronounced, between 1.36 and 1.87. It characterises a cumulative effect of plagioclase. One sample represented by a single liquid (D36) has a strongly enriched spectrum in medium REE compared to heavy REE $\left(\mathrm{La}_{\mathrm{N}} / \mathrm{Yb}_{\mathrm{N}}=2.97\right)$. There is a very slight negative anomaly in $\mathrm{Eu}, 0.91$, meaning a slight fractionation of plagioclase. This type of spectrum is similar to E-MORB.

Compared to N-MORB, most of the samples are clearly enriched in LREE and LIL elements and depleted in HREE ( $\mathrm{Y}$ and $\mathrm{Yb}$ ). N-MORB-normalised (Hofmann, 1988) spidergrams for the metabasalts and metagabbros are presented in Figure 7. They all display a nearly linear distribution characterised by decreasing abundances from LILE, $\mathrm{Ba}, \mathrm{Rb}$, Th and $\mathrm{K}$ down to HFSE. The regular slope is disturbed by a negative anomaly for $\mathrm{Nb}$ and $\mathrm{Ta}$ and positive $\mathrm{Pb}-\mathrm{Sr}$ peaks which are typical for magmas generated in subduction context. The Djabatoré spectra are slightly different, they are depleted in REE compared to MORB. Positive $\mathrm{Ti}$ and $\mathrm{Ta}$ anomalies mark the crystallization of ferro-titanium oxides in these magmas. The LILEs are enriched with respect to the REEs and the spectra show negative anomalies in some HFSEs ( $\mathrm{Nb}, \mathrm{Zr}$ and $\mathrm{Hf}$ ). These effects can be induced either by crustal contamination phenomena or by metasomatism of the source. In the latter case the hydration extends the field of stability of sphene and rutile, so these phases do not melt and trap the HFSE. The average of basic plutonic rocks from the Andean arcs display enrichment in LILE and some very incompatible HFSE such as Th, La and Ce compared to Kohistan oceanic arc rocks (Fig. 6). Kabyé and SE Ghana samples are closely similar to Andean samples, again 
suggesting a continental arc setting. Most Amalaoulaou rocks display trace elements distribution comparable to Kohistan basic rocks despite a large spread in LILE contents. Despite field evidences showing that the Agou complex intrudes the continental basement rocks, its chemistry is comparable to the intra-oceanic Kohistan arc rocks.

All the meta-igneous rocks from Amalaoulaou, Kabyé and Agou display very close isotopic features. They have fairly constant ${ }^{147} \mathrm{Sm} /{ }^{144} \mathrm{Nd}$ ratios between 0.1539 and 0.1818 , ${ }^{143} \mathrm{Nd} /{ }^{144} \mathrm{Nd}$ ratios between 0.5127 and 0.51288 , corresponding to initial $\varepsilon \mathrm{Nd}(\mathrm{T})$ values between +2.26 and +6.33 (Duclaux et al., 2006; Berger et al., 2011; Agbossoumondé et al., 2017) (Fig. 7). One meta-mafic rock from Agou and Kabyé show $\varepsilon N d(T)$ values close to 0 and one sample (TO153) from Kabyé show negative $\varepsilon \mathrm{Nd}(\mathrm{T})$ value. No $\mathrm{Sr}$ isotopic data are available from SE Ghana granulites, however, two granulites have $\varepsilon \mathrm{Nd}(\mathrm{T})$ values of +5.3 and +6.6 (Attoh and Smith, 2005) similar to the rest of the analysed samples.

Most of the samples have ${ }^{87} \mathrm{Sr} /{ }^{86} \mathrm{Sr}$ ratios rather low and range from 0.7015 to 0.7051 corresponding to $\varepsilon \operatorname{Sr}_{\mathrm{i}}(600 \mathrm{Ma})$ of -40 to -0.5 (Fig. 7). Such a large dispersion of isotopic values for $\mathrm{Sr}$ and $\varepsilon \mathrm{Nd}$ is indicative of the contamination of a depleted mantle in response to enrichment of the mantle wedge by fluids derived from subducted metasediments and/or a later assimilation of continental country rocks during the magma ascent and crystallisation (i.e. crustal contamination by the arc basement).

The particular sample, with negative $\varepsilon N d$ and $\varepsilon S r$ value close to 0 (TO 153), might be a good example of such a contaminated magma. Duclaux et al. (2006) noticed that the lack of correlation between the mafic $\varepsilon \mathrm{Nd}$ and $\mathrm{Nb}$ values indicating that $\mathrm{Nb}$ negative anomaly above is relative to the source composition rather than crustal contamination during the ascent of the magma throughout the crust. Two kyanite-bearing felsic granulites from the Kabyé massif were also analysed (Duclaux et al., 2006). Their negative $\varepsilon N d$ values and very high $\varepsilon \mathrm{Sr}$ clearly suggest a crustal origin deriving from an older crustal component, possibly related to the surrounding Paleoproterozoic basement. Calculations (De Paolo, 1981) by Duclaux et al. (2006) show that most of the samples are not contaminated by crustal material. Only the samples TO144B and TO153 from Kabyé show a sediment contribution at the source estimated between 3 and $10 \%$ respectively (Fig. 7).

A continental arc system would be a convenient setting for crustal contamination of mafic magmas deriving from an enriched mantle source. The base of the continental arc, built up by older gneisses, could represent a possible contaminant for ascending mafic magmas (Agbossoumondé et al., 2004; Duclaux et al., 2006). According to the $\mathrm{Nd}$ isotopic data, $\mathrm{Nd}$ model ages are estimated between $1 \mathrm{Ga}$ and $818 \mathrm{Ma}$, slightly younger than Bernard-Griffiths et al. (1991) 1.3 to $1.4 \mathrm{Ga} \mathrm{Nd}$ model ages. It is noticeable that the oldest Nd Model ages ( $>$ $950 \mathrm{Ma})$ estimated from Kabyé to SE Ghana and are interpreted as reflecting a mixing age between juvenile arc crust formed at ca. 630-610 Ma and pre-existing ca. $2100 \mathrm{Ma}$ Paleoproterozic crust of the Benino-Nigerian shield (Agbossoumondé et al., 2013). In contrast, in the Amalaoulaou massif, $\mathrm{Nd}$ model ages as young as $818 \mathrm{Ma}$ are only slightly older than the magmatic crystallisation ages. This together with the high positive $\varepsilon N d$ close to depleted mantle values obtained for Amalaoulaou samples reinforce the interpretation of an oceanic arc setting for this complex (Berger et al., 2011).

\section{Discussion}

\subsection{Along strike subduction system}

The lithological nature of complexes, dominated by garnet-bearing and garnet-free mafic 
rocks typical of plutonic arc complexes (DeBari and Greene, 2011), and the geochemical evidences demonstrate well the characteristic arc signature of the studied massifs. $\mathrm{SiO}_{2}$ content varies from 45 to $55 \mathrm{wt} \%$ with an alkaline content up to $5.95 \mathrm{wt} \%$ defining a general trend from basalts to trachy-andesites magmatic composition, symptomatic of the melting of a dominant upper mantle source (Fig. 4). Some samples have high $\mathrm{MgO}$ contents, up to 15.34 wt $\%$ which are typical of ultramafic and mafic cumulates. All the massifs show similar REE pattern with an enrichment of the LREE suggesting a similar source enriched with metasedimentary components. The multi-elements diagrams confirm the supra-subduction zone signature with an enrichment in LILE, $\mathrm{Ba}, \mathrm{Rb}, \mathrm{Th}, \mathrm{K}$, and a negative anomaly for $\mathrm{Nb}$ and Ta. The HREE depletion is classically related to partial melting of a garnet-bearing mantle source at depth greater than $90 \mathrm{~km}$.

$\mathrm{Sr}-\mathrm{Nd}$ isotopic data show however some striking differences between the massifs. In the case of the Amalaoulaou samples, isotopic compositions show homogeneous and depleted spectra (Fig. 7) very similar to the Tilemsi arc in Mali (Caby et al., 1989) which is considered as the upper crust superstructure (Berger et al., 2011). The Amalaoulaou complex is also very similar to the modern Izu-Bonin-Marianna intra-oceanic arc system (Stern et al., 2003). According to these results Berger et al. (2011) concluded that the Amalaoulaou complex is an intra-oceanic island arc active between $790 \mathrm{Ma}$ and $660 \mathrm{Ma}$. Similarly, $\varepsilon \mathrm{Nd}(\mathrm{T})$ compositions of SE Ghana are comprised between +5.3 and +6.6 (Attoh and Smith, 2005), unfortunately only few samples were analysed and no $\mathrm{Sr}$ isotopic data are available to conclude on the geodynamic setting (oceanic arc or continental arc). In contrast, the $\mathrm{Sr}-\mathrm{Nd}$ isotopic composition of the Kabyé and Agou massifs are more dispersed with $\varepsilon N d(T)$ values comprised between +9 and -6 (Fig. 7) suggesting contamination by a continental crust component during their emplacement. The early emplacement of the Kabyé massif in the continental basement is confirmed by the occurrence of two kyanite-bearing felsic gneisses showing strong $\varepsilon N d$ values $(<-10)$ and high $\varepsilon \mathrm{Sr} \quad(>500)$ symptomatic of the surrounding Paleoproterozoic basement. Moreover, field evidences show that the Agou massif is emplaced within this Paleoproterozoic continental basement (Aicard, 1957; Agbossoumondé, 2004). Although previous authors (Agbossoumondé, 2004, 2013; Duclaux et al., 2006) concluded that these massifs are emplaced in a continental margin, we can precise the geodynamic setting of those massifs. In fact, the lower unit of Kabyé massif is dominated by ultramafic to depleted mafic rocks without any evidence of continental contribution while the upper unit is more differentiated with basalts and trachy-andesites and cross-cut by felsic dyke having a clear continental signature. A possibility to reconcile the difference between the lower and upper units is to propose that the Kabye massif corresponds to two arc systems. In this context, the lower unit was equivalent to the Amalaoulaou intra-oceanic arc, while the upper unit emplaced within the continental margin. However, there is neither evidence of suture zone between both unit (absence of serpentinites), nor any difference in age. The second solution, that we favour, is that the lower unit developed in a forearc position in front of the trench, while the upper unit emplaced in the more internal part on the continental margin. Such a geodynamic setting is well exposed and well known along the Himalayan belt in where the Kohistan-Ladakh-Xigaze forearc system developed synchronously with the active margin magmatism (Mahéo et al., 2004; Dhuime et al., 2007; Maffione et al., 2015).

As already discussed, the Agou massif emplaced within the active continental margin, such as the Djabatoré and Notsé massif located more to the east relative to the paleo-trench. In SE Ghana a similar situation is proposed with the emplacement of the mafic units within the surrounding continental gneisses (Attoh, 1997). Further to the north, east of the Amalaoulaou -Tilemsi arc system, the active continental margin setting is also well expressed in the Adrar des Iforas (Fig. 1b) where tonalitic plutons dated between $716 \pm 5 \mathrm{Ma}$ and $696 \pm 6 \mathrm{Ma}$ (Caby and Andréopoulos-Renaud, 1985; Bruguier et al., 2008) are exposed and overlaid with a 
volcano-sedimentary deposition sequence dated at $630 \pm 13$ Ma (Liégeois, 1988). Finally, numerous calc-alkaline granitoids with a continental arc affinity and dated between 670 and $610 \mathrm{Ma}$ emplaced east of the suture zone from the Adrar des Iforas to SE Ghana marking the flare up activity of the continental active margin (Liégeois et al., 1987; 1998; Kalsbeek et al., 2012; Attoh et al., 2013; Ganade et al., 2016).

Thus, to conclude from north to south along the Dahomeyide belt, the subduction system related to the closure of the Pharusian ocean (Fig. 9a-b) evolved from a double subduction system (intra-oceanic arc and active continental margin) in the north to a single active continental margin to the south (Fig. 9c). This system continues south to the NE Brazil and form a Neoproterozoic $>2500 \mathrm{~km}$ long subduction system (Ganade de Araujo et al., 2014; 2016) equivalent to the Cretaceous Tethyan subduction system along the South Asian margin.

\subsection{Implication of the arc system in the collision zone}

A specificity of the studied zone is the strong granulitic imprint recorded by the metagabbros. Surprisingly from Mali to Togo, all the studied metagabbros recorded a coronitic metamorphic evolution marked by the crystallisation of a garnet + clinopyroxene coronas around the primary magmatic orthopyroxene + plagioclase assemblage (Fig. 3). This metamorphic evolution is related to a pressure increase from 7-9 kbar (corresponding to the pressure of emplacement of the magmas) to $10-14 \mathrm{kbar}$ and exceptionally up to $18 \mathrm{kbar}$ in the lower Kabyé unit with a slight temperature cooling from ca. $900{ }^{\circ} \mathrm{C}$ (temperature of crystallization of the melt) down to $750-850{ }^{\circ} \mathrm{C}$ (Fig. 8). Berger et al. (2011) interpreted this granulisation as related to the thickening of the root of the magmatic arc between 793 and 660 Ma as inferred in the Kohistan arc (Dhuime et al., 2007; Garrido et al., 2007). In contrast Attoh (1998), Agbossoumondé et al. (2004), and Duclaux et al. (2006) related this granulitisation event dated between 620 and 610 Ma from Kabyé to SE Ghana to the burial of the arc system. However, the epidote amphibolite unit forming the sole of the Amalaoulaou complex yielded P-T conditions around $520{ }^{\circ} \mathrm{C}$ and $9 \mathrm{kbar}$ that are abnormally cold compared to intra-oceanic granulitic metamorphism recorded in the metagabbro unit. We suggest that this low temperature sole evidence the incorporation of the Amalaoulaou complex in the Early Ediacarian subduction-collision system. To explain the absence of mineralogical evidences for a subduction metamorphism imprint in some units, Duclaux et al. (2006) showed in the Kabyé massif that crystallisation of granulitic parageneses is composition-dependent. As example and in the case of magmatic layering, even at the thin-section scale, the more ferromagnesian metagabbros preserved the magmatic assemblages while the more differentiated gabbros developed granulitic texture and mineralogy. The same kind of evolution is well documented in eclogitic massifs such as the Monviso in the Alps where the classical eclogitic paragenesis developed in Fe-Ti metagabbros while the Mg-metagabbros are garnet free (Schwartz et al., 2000). This absence of metamorphic garnet in Mg-rich rocks is well known and related to the crystallisation of garnet at higher pressure (Spear 1993). The burial of the arc system occurred synchronously with the continental subduction of the eastern margin of the Western African Craton and marked by the occurrence of HP-UHP continental eclogites dated at 609-611 $\mathrm{Ma}$ in the Lato and Gourma massif (Bernard-Griffiths et al., 1991; Agbossoumondé et al., 2002; Ganade de Ajauro et al., 2014). The absence of HP-LT, symptomatic of a cold subduction gradient in the studied massifs is not an exceptional situation worldwide especially in forearc setting. In the North Andes, Riel et al. (2013) show that the base of the forearc recorded, during the Permo-Triassic subduction, the emplacement of mantellic magma that triggered partial melting of the crust, just before the underplating of amphibolitic slices. In Oman, the HP-LT metamorphism recorded in the subducting plate is preceded by $10 \mathrm{Myr}$, by a granulitisation $\left(850 \pm 50^{\circ} \mathrm{C}\right)$ followed by a cooling under 
amphibolite metamorphic conditions (Prigent et al., 2018). Similarly, in Dominican Republic, Krebs et al. (2008) show that the onset of the Atlantic subduction is characterised by an increase of the P-T conditions from $600^{\circ} \mathrm{C}, 14 \mathrm{kbar}$ to $750^{\circ} \mathrm{C}, 22 \mathrm{kbar}$ before cooling along a "normal" subduction geothermal gradient. All these geodynamic situations reveal that heating in the forearc mantle is due to asthenospheric upwelling when slab roll-backs or slab retreats occurred (Jolivet et al. 2003). We thus propose that the onset of the continental subduction of the WAC by ca. $640 \mathrm{Ma}$ (metamorphic age of the Kara quartzites) engaged the tip of the arc system within the continental system and buried it from $18-27 \mathrm{~km}$ up to locally $50-55 \mathrm{~km}$ (Fig. 9c) between 620 and $610 \mathrm{Ma}$. Experimental and numerical modelling Chemenda et al. (2001) and Boutellier et al. (2003) shown that during oceanic or continental subduction, the rupture of the upper plate is physically quite plausible. The conditions for the weakening of the upper plate are prepared during oceanic subduction. Such weakening occurs by upwelling of the mantle lithosphere in the forearc region due to back-arc spreading. As weakening becomes sufficient and the subduction regime shifts from tensional to compressional, rupture occurs within the arc. Partial or complete subduction of the forearc occurs during the subduction of the continental margin. Then with the increasing of the buoyancy due to the subduction of the continental felsic material inducing a steepening of the continental subduction, both a part of the subducted arc or forearc system and the HP-UHP continental rocks were exhumed together (Boutellier et al., 2008; Guillot et al., 2009) (Fig. 9d). This scenario clearly explains how the arc system (upper plate) along the Gourma-Dahomeyide belt recorded the burial down to $50-55 \mathrm{~km}$ coevally with the burial of the WAC continental margin at a minimum depth of ca. $100 \mathrm{~km}$ (lower plate) (Fig. 9c).

This scenario also can potentially explain why the intra-oceanic arc is not preserved or exhumed all along the Dahomeyide belt. East of the suture zone, around the Kandi fault, there are magmatic and geochronological evidences that the continental margin was active between $670 \mathrm{Ma}$ and $610 \mathrm{Ma}$. Moreover, Ganade et al. (2016) dated detrital zircon from a partially melted metasedimentary rock, east of Kabyé, up to $781 \mathrm{Ma}$ and proposed to relate this earlier magmatism to the active margin activity while the oldest age recorded in the arc system is in SE Ghana at $650 \mathrm{Ma}$ (Attoh et al., 1991). In this hypothesis, the positive Bouguer anomaly observed beneath the Kandi Fault and not beneath the suture zone (El-Hadj Tidjani et al., 1997) highlights the occurrence of a massive mafic body at the base of the crust that could correspond to the underplated buried forearc (Fig. 9d).

We thus propose that in the Dahomeyide belt, from Kabyé to SE Ghana, the arc system probably onset at ca. 800-780 Ma (Fig. 9a) as observed more to the north in the Gourma and Adrar des Iforas or more to the south in Brazil (e.g. Ganade de Ajaujo et al., 2014; 2016) but a large part of the frontal part of the arc system was buried and not exhumed during the collision.

\section{Conclusion}

Petrological, geochemical and geochronological review of the ultramafic to mafic massifs along the $1000 \mathrm{~km}$-long Dahomeyide belt allow proposing a global scenario for the closure of the Pharusian ocean between the Western African Craton and the Benino-Nigerian shield during the Neoproterozoic. The onset of oceanic subduction by 800-780 Ma is partly recorded by the dating of earlier magmatism in the Amalaoulaou intra-oceanic arc in Mali (Fig. 9a). This intra-oceanic arc has a long-lived history, till ca. $660 \mathrm{Ma}$. In parallel, onset of active margin subduction $720 \mathrm{Ma}$ ago beneath the Benino-Nigerian shield and its northward prolongation in Mali is emphasised by the first occurrence of tonalitic plutons (Fig. 9b) and the development of a forearc system $650 \mathrm{Ma}$ ago. This second oceanic subduction beneath the active margin ended between 640 and 630 Ma with the onset of subduction of the WAC 
continental margin while the subduction related magmatism continues till ca. $600 \mathrm{Ma}$ on the upper plate. During this short period (620-610 Ma), the forearc system and the tip of the active continental margin were involved and buried at a maximum depth of $55 \mathrm{~km}$ synchronously with the continental subduction of the tip of the WAC margin at a depth of ca. $100 \mathrm{~km}$ (Fig. 9c). Finally, the transition from continental subduction (soft collision) to continental collision (hard collision) between 610 and $580 \mathrm{Ma}$ is marked by the exhumation and partial amphibolitization of the suture zone and by the shift from a calc-alkaline magmatism to anatectic magmatism and the onset of strike-slip faulting in the upper plate. A similar tectono-metamorphic evolution is also recorded southward in NE Brazil highlighting a 2500-km Himalayan type mountain belt (Ganade de Araujo, 2014; 2016). However, to our knowledge, it represents a unique example in the world where the forearc system is buried and partly exhumed at the transition from subduction to collision and opens the question of the meaning of coronitic granulites and more generally of HP granulites observed in the root of ancient mountain belts (e.g. Hacker et al., 2015).

\section{Acknowledgments}

This project was funded by the Labex OSUG@2020 (ANR10 LABX56). We acknowledge Carlos E. Ganade and the editor Randall Parrish for their constructive comments.

\section{References}

Abdelsalam, M.G., Liégeois, J.P., Stern, R.J. 2002. « The Saharan Metacraton ». J Afr. Earth Sci. 34, 119-136.

Adissin Glodji, L., 2014. La zone de cisaillement de Kandi et le magmatisme associé dans la région de Savalou-Dassa (Bénin) : étude structurale, pétrologique et géochronologique. Thesis, University of Saint-Etienne, France p. 260.

Adissin Glodji, L., Bascou, G.Y., S. Ménot, R.P. Villaros, A., 2014. Relationships between deformation and magmatism in the Pan-African Kandi Shear Zone: Microstructural and AMS studies of Ediacaran granitoid intrusions in central Bénin (West Africa). J. Afr. Earth Sci. 97, 143-160.

Affaton, P., Rahaman, M.A., Trompette, R., Sougy, J., 1991. The Dahomeyide orogeny: Tectonothermal evolution and relationships with the Volta basin. In : Dallmeyer R.D. \& Lecorché J.P. (Eds.). The West African Orogens and Circum-Atlantic Correlations. Springer Verlag, Berlin, 107-122.

Affaton, P., Kröner, A., Seddoh, K.F., 2000. Pan-African granulite formation in the Kabyé Massif of the northern Togo (West Africa) : Pb-Pb zircon ages. Int. J. Earth Sci. 88, 778790.Agbossoumonde, Y., Ménot, R.P., Guillot, S., 2001. Metamorphic evolution of Neoproterozoic eclogites from south Togo (West Africa). J. Afr. Earth Sci. 33, 227-244.

Agbossoumonde, Y., Ménot, R.P., Guillot, S., 2004. Pan-African subduction-collision event evidenced by high-P granulites from Agou Massif in southern Togo (West Africa). Precambr. Research 135, 1-21.

Agbossoumonde, Y., Ménot, R.P., Paquette, J.L., Guillot, S., Yéssoufou, S., Perrache, C., 2007. Petrological and geochronological constraints on the origin of the Palimé-Amlamé granitoids (South Togo, West Africa): a segment of the West African Craton Paleoproterozoic margin reactivated during the Pan-African collision. Gondwana Res. 12, 476-488.

Agbossoumondé, Y., Ménot, R.P., Nude, P.M., 2013. Geochemistry and Sm-Nd isotopic composition of the Agou Igneous Complex (AIC) from the Pan-African orogen in southern 
Togo,West Africa: Geotectonic implications. J. Afr. Earth Sci. 82, 88-99.

Agbossoumonde, Y., Ménot, R.P., Ganade de Araujo, C.E., 2017. Major, Trace Elements and Sr-Nd Isotopic Characteristics of High-Pressure and Associated Metabasites from the PanAfrican Suture Zone of Southern Togo, West Africa. J. Environ. Earth Sci. 7, 17-31.

Agyei EK, v.L.J., Armstrong RL, Harakal JE, Scott KL 1987. RB-Sr and K-Ar geochronology of southeastern Ghana. J Afr. Earth Sci. 6, 153-161.

Aicard, P., 1957. Le Précambrien du Togo et du Nord-Ouest du Dahomey. Doctoral thesis, Univ Nancy and Bulletin Direction Fédéral Mines et Géologie, Dakar 23, P. 226.

Attoh, K., 1998. High pressure granulite facies metamorphism in the Pan-african Dahomeyide orogen, West Africa. J. Geol. 106, 236-246. Attoh, K., Hawkins, D., Bowring, S.A., Allen, B., 1991. U-Pb zircon ages of gneisses from Panafrican Dahomeyide orogen, West Africa. EOAS Trans. Amer. Geophy. union 72, 299.

Attoh, K., Dallmeyer, R.D., Affaton, P., 1997. Chronology of nappe assembly in the PanAfrican Dahomeyide orogen, West Africa : evidence from 40Ar/39Ar mineral ages. Precambr. Research 82, 153-171.

Attoh, K., Morgan, J., 2004. Geochemistry oh high-pressure granulites from the Pan- African Dahomeyide orogen, West Africa: constraints on the origin and composition of the lower crust. J. Afr. Earth Sci. 39, 201-208.

Attoh, K., Schmitz, M.D., 2005. Nd and Hf isotopic compositions of Pan-African highpressure mafic granulites. EOS Trans. Amer. Geophys. Union 86(18) Joint Ass. Supp. V13B-02

Attoh, K., Nude, P.M., 2008. T , 297, pp. 217-231., 2008. Tectonic significance of carbonatite and ultra high-pressure rocks in the Pan- African Dahomeyide suture zone, southeastern Ghana. In: Ennih, N., Liégeois, J.-P. (Eds.), The Boundaries of the West African Craton,. Geol. Soc. London Spec. Pub. 297, 217-231.

Attoh K., S.S., Agbossoumondé Y., Nude P.M., Morgan J., 2013. Geochemical characteristics and $\mathrm{U}-\mathrm{Pb}$ zircon LA-ICPMS ages of granitoids from the Pan-African Dahomeyide orogen, West Africa. J. Afr. Earth Sci. 79, 1-9.

Berger, J., 2008. Les associations de roches basiques - ultrabasiques néoprotérozoïques d'Amalaoulaou (Gourma, Mali), du Tassendjanet (Hoggar occidental, Algérie) et cénozoïques du Saghro (Anti-Atlas, Maroc): témoins de l'évolution géodynamique de la ceinture péri-cratonique ouest-africaine. Ph-D Université Libre de Bruxelles, p. 405.

Berger, J.C., R Liégeois, JP Mercier, JCC Demaiffe, D., 2009. Dehydration, melting and related garnet growth in the deep root of the Amalaoulaou Neoproterozoic magmatic arc (Gourma, NE Mali). Geol. Mag. 146, 173-186.

Berger, J., Caby, R. Liégeois, JP Mercier, JCC, Demaiffe, D., 2011. Deep inside a neoproterozoic intra-oceanic arc: growth, differentiation and exhumation of the Amalaoulaou complex (Gourma, Mali). Am. Mineral. 162, 773-796. Bernard-Griffiths, J., Peucat, J.-J., Ménot, R.P., 1991. Isotopic (Rb-Sr, U-Pb and Sm-Nd) and trace element geochemistry of eclogites from the pan-African Belt : A case study of REE fractionation during high-grade metamorphism. Lithos 27, 43-57.

Boutelier, D., Chemenda, A.I., Burg, J.P., 2003. Subduction versus accretion of intra-oceanic volcanic arcs: insight from thermo-mechanical analogue experiments. Earth Planet. Sci. Lett. 212, 31-45.

Boutelier, D., Chemenda, A., 2008. Exhumation of UHP/LT rocks due to the local reduction of the interplate pressure: Thermo-mechanical physical modelling. Earth Planet. Sci. Lett. 271, 226-232. Bruguier, O., Bosch, D, Caby, R, Galland, B, Hammor, D, Geochim, Acta, C., 2008. Sampling an active continental paleo-margin: a LA-ICP-MS U-Pb zircon study from the Adrar des Iforas (Mali). Geoch. Cosmochim. Acta 72:A118.

Buscail, F., Caby, R., 2005. Notice explicative et carte géoologique du Gourma oriental au 
1/200 000 Ansongo-Amalaoulaou. Direction Nationale des Mines et de la Géologie, Bamako, Mali.

Caby, R., 1987. The Pan-African belt of West Africa from the Sahara desert to the Gulf of Benin, in: Press, P.U. (Ed.), The Anatomy of Mountain Ranges, Princeton, New Jersey, 129-170.

Caby, R., 1989. Precambrian terranes of Benin-Nigeria and northeast Brazil and the Late Proterozoic south Atlantic fit. Geol. Soc. Am. Sp. Paper 230, 145-158.

Caby, R., 1994. Precambrian coesite from northern Mali : first record and implications for plate tectonics in the Trans-Saharan segment of the Pan-African belt. Eu. J Mineral. 6, 235244.

Caby, R., 2003. Terrane assembly and geodynamic evolution of central-western Hoggar: a synthesis. J. Afr. Earth Sci. 37, 133-159.

Caby, R., Andreopoulos-Renaud, U., Lancelot, J.R., 1985. Les phases tardives de l'orogénèse pan-africaine dans l'Adrar des Iforas Oriental (Mali) : lithostratigraphie des formations molassiques et géochronologie $\mathrm{U} / \mathrm{Pb}$ sur zircon de deux massifs intrusifs. Precambr. Res. 28, 187-199.

Caby, R., Buscail, F., Dembéle, D., Diakité, S., Sacko, S., Bal, M., 2008. Neoproterozoic garnet-glaucophanites and eclogites: new insights for subduction metamorphism of the Gourma fold and thrust belt (eastern Mali). In "The Boundaries of the West African Craton", Ennih, N. \& Liégeois, J.P. (eds). Geological Society, London Special Publications, 297, 203-216.

Castaing, C., Triboulet, C., Feybesse, J.L., Chèvremont, P., 1993. Tectonometamorphic evolution of Ghana, Togo and Benin in the light of the Pan-African/Brasiliano orogeny. Tectonophy. 218, 323-342.

Chemenda, A.I., Hurpin, D.,. Tang, J.-C., Stephan, J.-F., and Buffet, G.,, 2001. Arc-continent collision and mechanism for the burial and exhumation of UHP/LT rocks: constraints provided by experimental and numerical modelling. Tectonophy. 342, 137-161.

Daoudene, 2005. Pétrologie et Chimie d'une granulite et d'une éclogite, Togo, Afrique de l'Ouest. Master, University of Lyon, France, p. 13 ..

De La Boisse, H., 1979. Pétrologie et géochronologie des roches cristallophylliennes du bassin des Gourma (Mali). Conséquences géodynamiques. Thesis, University of Montpellier, France.

DeBari, S.M., Greene, A.R., 2011. Vertical Stratification of Composition, Density, and Inferred Magmatic Processes in Exposed Arc Crustal Sections. Arc-Continent Collision. Springer Berlin Heidelberg, 121-144.

DePaolo, D.J., 1981. Trace element and combined wallrock assimilation and fractional crystallisation. Earth Planet. Sci. Lett. 53, 189-202.

Dhuime, B., Bosch, D., Bodinier, J.L., Garrido, C.J., Brugier, O., Hussain, S.S., Dawood, H., 2007. Multistage evolution of the Jijal ultramafic-mafic complex (Kohistan, N pakistan): implications for building the roots of island arcs. Earth Planet. Sci. Lett. 261, 179-200.

Doblas, M., Lopez-Ruiz, J., Cebria, J.M., Youbi, N., Degroote, E., 2002. Mantle insulation beneath West African Craton during the Precambrian-Cambrian transition. Geology 30, 838-842.

Duclaux, G., 2003. Le magmatisme basique du Nord Togo témoin de l'orogenèse Panafricaine. Master, University of Lyon, France, p. 89.

Duclaux, G., Ménot, R.P., Guillot, S., Agbossoumondé, Y., Hilairet, N., 2006. Geochemical evidence of an a Pan-african intra-oceanic arc in the Kabyé massif (North Togo). Precambr. Res. 151, 101-118.

El-Hadj Tidjani, M., Affaton, P., Louis, P., Socohou, A., 1997. Gravity characteristics of the Pan-African orogen in Ghana, Togo and Benin (West Africa). J. Afr. Earth Sci. 24, 241- 
258.

Ganade de Araujo, C.E., Rubatto, D., Hermnn, J., Cordani, U.G., Caby, R., Basei, M.A.S., 2014. Ediacaran $2500 \mathrm{~km}$ long synchronous deep continental subduction in the west Gondwana orogen. Nature com. 5.

Ganade de Araujo, C.E., Rubatto, D., Hermnn, J., Cordani, U.G., Caby, R., Basei, M.A.S., Weinberg, R.F., Sato, K., 2016. Tightening-up NE Brazil and NW Africa connections: advances in zircon geochronology towards a complete plate tectonic cycle in the Dahomeyide belt of the West Gondwana Orogen in Togo and Benin. Precambr. Res. 276, $29-42$.

Garrido, C.J., Bodinier, J.L., Dhuime, B., Bosch, D., Chanefo, I., Bruguier, O., Hussain, S.S., Dawood, H., Burg, J.P., 2007. Origin of the island arc Moho transition zone via melt-rock reaction and its implications for intracrustal differentiation of island arcs: evidence from the Jijal complex (Kohistan complex, northern Pakistan). Geology 35, 683-686.

Guillot, S., Hattori, K., Agard, P., Schwartz, S., Vidal, O., 2009. Exhumation processes in oceanic and continental subduction contexts: a review. In S. Lallemand and F. Funiciello (eds.) "Subduction Zone Dynamics", Springer-Verlag Berlin Heidelberg. doi : 10.1007/978-3-540-87974-9, 175-204.

Hacker, B.H., Kelemen, P.B., Behn, M.D., 2015. Continental Lower Crust. Annual Rev. Earth Planet. Sci. 43, 167-205.

Hilairet, N., 2004. Le massif granulitique HP de Kabyé (Nord Togo), témoin d'un arc continental impliqué dans l'orogenèse Panafricaine. Master, Univerity of Lyon, France, p. 56

Hirdes, W., Davis, D.W., 2002. U-Pb zircon and rutile metamorphic ages of Dahomeyan garnet-hornblende gneiss in southeastern Ghana, West Africa. J. Afr. Earth Sci. 35, 445449.

Hoffman, P.F., Kaufman, A.J., Halverson, G.P., Schrag, D.P., 1998. A Neo-Proterozic snowball. Earth Sci. 281, 1342-1346.

Jahn, B.-M., Caby, R., Monie, P., 2001. The oldest UHP eclogites in the world: age of UHP metamorphism, nature of protoliths and tectonic implications. Chem. Geol. 178, 143-158.

Jolivet, L., Faccenna, C., Goffé, B., Burov, E., Agard, P., 2003. Subduction tectonics and exhumation of high-pressure metamorphic rocks in the Mediterranean orogens. Am. J. Sci. 303, 353-409.

Kalsbeek, F., Affaton, P., Ekwueme, B., Freid, R., Thranea, K., 2012. Geochronology of granitoid and metasedimentary rocks from Togo and Benin, West Africa: comparisons with NE Brazil. Precambr. Res. 196, 218-233.

Krebs, M., Maresh, W.M., Schertl, H.P., Baumann, A., Draper, G., Ildeman, B., Münker, C., Trapp, E., 2008. The dynamics of intra-oceanic subduction zones: A direct comparison between fossil petrological evidence (Rio San Juan Complex, Dominican Republic) and numerical simulation. Lithos 103, 106-137.Liégeois, J.P., 1988. Le batholite composite de l'Adrar des Iforas (Mali). Académie Royale des Sciences d'Outre-Mer. Classe Sci Nat et Med Mém. 8, P. 231.

Liégeois, J.P., Bertrand, H., Black, R., 1987. The subduction- and collision-related PanAfrican composite batholith of the Adrar des Iforas (Mali) : a review. Geol. J. 22, 185-211.

Liegeois, J.P., Navez, J., Hertogen, J., Black, R., 1998. Contrasting origin of post-collisional high-K calc-alkaline and shoshonitic versus alkaline and peralkaline granitoids. The use of sliding normalization. Lithos 45, 1-18.

Maffione, M., van Hinsbergen, D.J.J., Louise, M.T.K., Guilmette, C., Hodges, K.V., Borneman, N., Huang, W., Ding, L., Kapp, P., 2015. Forearc hyperextension dismembered the south Tibetan ophiolites. Geology 43, 475-478.

Mahéo, G., Bertrand, H., Guillot, S., Keller, F., Capiez, P., 2004. The South Ladakh ophiolite 
(NW Himalaya, India), a crustal and upper mantle section of the same immature arc: implications for the closure of the Neothethys. Chem. Geology 203, 273-303.

Ménot, R.-P., 1980. Les massifs basiques et ultrabasiques de la zone mobile pan-africaine au Ghana, Togo et Bénin. Bull. Soc. Geol. Fr. XXII(3), 297-303.

Ménot, R.P. and Seddoh, K.F. (1981). Le massif basique stratifié précambrien de DjabatoréSoutouboua (Région centrale du Togo, Afrique de l'Ouest). Pétrographie et évolution métamorphique. Bulletin du B.R.G.M. (deuxième série), section IV, n4-1980-1981, 319337.

Ménot, R.P., Seddoh, K.F., 1985. The eclogites of the Lato Hills, South Togo, West Africa : relics from the early tectonometamorphic evolution of the Pan-African orogeny. Chem. Geol. 50, 313-330.

Nude, P.M., Shervais, J.W., Attoh, K., Vetter, S.K., Corey Barton, C., 2009. Petrology and geochemistry of nepheline syenite and related carbonate-rich rocksin the Pan-African Dahomeyide orogen, southeastern Ghana, West Africa. J. Afr. Earth Sci. 55, 147-157.

Pearce, J.A., Cann, J.R., 1973. Tectonic setting of the basic volcanic rocks detremined uisng trace element analysis. Earth Planet. Sci. Lett. 19, 290-300.

Prigent, C., Guillot, S., Agard, P., Ildefonse, P., 2018. Fluid-assisted deformation and strain localization in the cooling mantle wedge of a young subduction zone (Semail Ophiolite). J. Geophys. Res. 123, doi.org/10.1029/2018JB015492

Riel, N., Guillot, S., Jaillard, E., Martelat, J.E., Paquette, J.L., Schwartz, S., Goncalvez, P., Duclaux, G., Thiebaud, N., Lanari, P., Janots, E., Yuquilema, J., 2013. Implications for high-temperature metamorphism in a forearc zone: a metamorphic and geochronogical study of the Triassic El Oro metamorphic complex in Ecuador. Lithos doi: .org/10.1016/j.lithos.2012. 10.005 .

Santos, T.J.S., Garcia, M.G.M., Amaral, W.S., Caby, R., Wernick, E., Arthaud, M. H., Dantas, E. L., Santosh, M., 2009. Relics of eclogite-facies assemblages in the Ceara' Central Domain, NW Borborema Province, NE Brazil: Implications for the assembly of West Gondwana. Gondwana Res. 15, 454-470.

Santos, T.J.S., Amaral, W.S., Ancelmi, M.F., Pitarello, M.Z., Fuck, R.A., Dantas, E.L., 2015. $\mathrm{U}-\mathrm{Pb}$ age of the coesite-bearing eclogite from NWBorborema Province, NE Brazil: Implications for western Gondwana assembly. Gondwana Res. 28, 1183-1196.

Schwartz, S., Lardeaux, J.M., Guillot, S., Tricart, P., 2000. Diversité du métamorphisme éclogitique dans le massif ophiolitique du Monviso (Alpes Occidentales, Italie). Geodin. Acta 13, 169-188.

Spear, F.S., 1993. Metamorphic Phase Equilibria and Pressure-Temperature-Time Paths. Mineralogical Society of America, Monograph series, P. 799.

Stern, R.J., Fouch, M.J., Klemperer, S.L., 2003. An overview of the Izu-Bonin-Mariana subduction factory. In: Eiler J, Hirschmann M (eds) Inside the subduction factory. Geophysical monograph. Amer. Geophy. Union 138, 175-222.

Tairou, M.S., Affaton, P., 2013. Structural organization and tectono-metamorphic evolueion of the Pan-African suture zone: case of the Kabye and Kpaza massifs in the Dahomeyide orogen in Northern Togo (West Africa). International Journal of Geosciences, 4, 166-182.

Tatsumi, Y., 1989. migration of fluid phases and genesis of basalt magmas in subduction zone. J. Geophys. Res. 94, 4697-4707.

Trompette, R., 2000. Gondwana evolution; its assembly at around $600 \mathrm{Ma}$. Earth and Planetary Sciences 330, 305-315.

Veevers, J.J., 1995. Emergent long lived Gondwaland vs submergent, shortlived Laurasia: supercontinental and Pan-African heat imparts long-term buyonacy by mafic underplating. Geology 23, 1131-1134. 
Figure captions

Fig. 1. Location of the study area. a) Geological map of the West Africa. b) Geological map of the Dahomeyide belt, modified from Agbossoumondé et al. (2004) and Berger et al. (2011).

Fig. 2. West-East cross-section from the Volta basin to the Benino-Nigerian shield at the latitude of the Kabyé massif with the main geological units. 1) slightly very low grade metasediments (cf. Affaton et al., 1997) of the Buem structural unit. 2) External nappes of the Atacora composed of lower amphibolite facies quartzite and micaschists. 3) Eclogites from the Lato continental unit (accretionary prism). 4) Banded granulites from the upper Kabyé unit. 5) Kyanite-bearing felsic granulite from the upper Kabyé unit. 6) Granulitic metagabbro from the Agou massif. 7) Granulitic gneisses sheared within the Kandi shear zone. 8) Metasedimentary gneisses from the Benino-Nigerian shield. 9) Felsic granulites from the Benino-Nigerian shield.

Fig. 3. Thin-section photos of the coronitic granulites. a) Grt porphyroblast preserving inclusions of Cpx, Pl and Rt in the Amalaoulaou metagabbro (from Berger et al., 2011). b) Development of coronitic Cpx around the magmatic Opx in a matrix of Pl (upper Kabyé unit metagabbro). c) Development of Opx corona around $\mathrm{Ol}$ and amp-sp around $\mathrm{Pl}$ in troctolitic metagabbro (Djabatouré massif). d) Corona of $\mathrm{Cpx}+\mathrm{Grt}+\mathrm{Qtz}$ around magmatic Opx in the Agou metagabbro (from Agbossoumondé et al., 2004). e) Corona of Am+Pl+Ky around magmatic Opx in from SE Ghana metagabbro (from Attoh, 1998). f) Grt bearing amphibolite from the Notsè massif.

Fig. 4. Whole rock compositions of the metagabbros and metadolerites from the main maficultramafic massifs in the $\mathrm{SiO}_{2}$ vs $\mathrm{Na}_{2} \mathrm{O}+\mathrm{K}_{2} \mathrm{O}$ diagram. (Data from Attoh and Morgan, 2004 ; Duclaux et al., 2006 ; Berger et al., 2011 ; Agbossoumondé et al., 2013).

Fig. 5. Primitive mantle normalised REE patterns of the metagabbros from the main maficultramafic massifs. (Data from Attoh and Morgan, 2004 ; Duclaux et al., 2006 ; Berger et al., 2011; Agbossoumondé et al., 2017).

Fig. 6. N-MORB normalised multi-element diagrams of the metagabbros from the main studied mafic-ultramafic massifs. (Data from Attoh and Morgan, 2004; Duclaux et al., 2006 Berger et al., 2011; Agbossoumondé et al., 2017)

Fig. 7. Sr-Nd isotopic composition of the metagabbros from the main studied maficultramafic massifs. (Data from Attoh and Morgan, 2004; Duclaux et al., 2006 Berger et al., 2011; Agbossoumondé et al., 2017)

Fig. 8. Pressure-Temperature time paths from the main studied mafic-ultramafic massifs including the continental eclogitic units (see text for discussion); Three stages are distinguished: (i) magmatic crystallization (800-620 Ma); (ii) arc docking corresponding to the buried of the tip of the arc, synchronously with the continental subduction of the WAC margin (620-610 Ma); (iii) amphibolitisation and exhumation during collision (600-580 Ma). 
Fig. 9. Proposed tectonic evolution of the Dahomeyide belt from Neoproterozoic to Ediacaran corresponding to the closure of the Pharusian ocean (modified from Agbossoumondé et al., 2004 ; Berger, 2008; Ganade et al., 2016) (see text for discussion).

Table 1. Temporal distribution of the main lithotectonic units from the upper plate (Western African Craton), the arc system to the upper plate (Benino-Nigerian Shield); references are cited in the text.

Table 2. Compilation of the published geochronological data from the Pharusian suture zone

Table 3. Lithology of the principle studied samples in Amaloulaou (Berger et al., 2011); Kabyé (Attoh et al., 1997; Duclaux et al., 2006); Agou (Attoh, 1998; Agbossoumondé et al. 2004); SE Ghana (Attoh and Morgan, 2004; Attoh and Smith, 2005) and Djabatoré (Duclaux, 2003).

Table 4: Compilation of the published geochronological data from the main mafic-utramafic massifs. Amalaoulaou (Berger et al., 2011), the Kabyé (Duclaux et al., 2006), Agou (Agbossoumondé et al., 2013); Djabatoré (Duclaux, 2003) and SE Ghana (Attoh and Morgan, 2004; Attoh and Smith, 2005).

The suture zone of the Dahomeyide belt, exposed coronitic HP granulitic massifs.

The closure of Pharusian ocean occurred along intra-oceanic arc and active margin from 800 to $600 \mathrm{Ma}$

Between 620 and $610 \mathrm{Ma}$, the forearc system and the tip of the active continental margin were buried synchronously

The positive Bouguer anomaly East of the suture zone, could correspond to the underplated buried forearc

The transition from continental subduction to continental collision occurred between 610 and $580 \mathrm{Ma}$ 

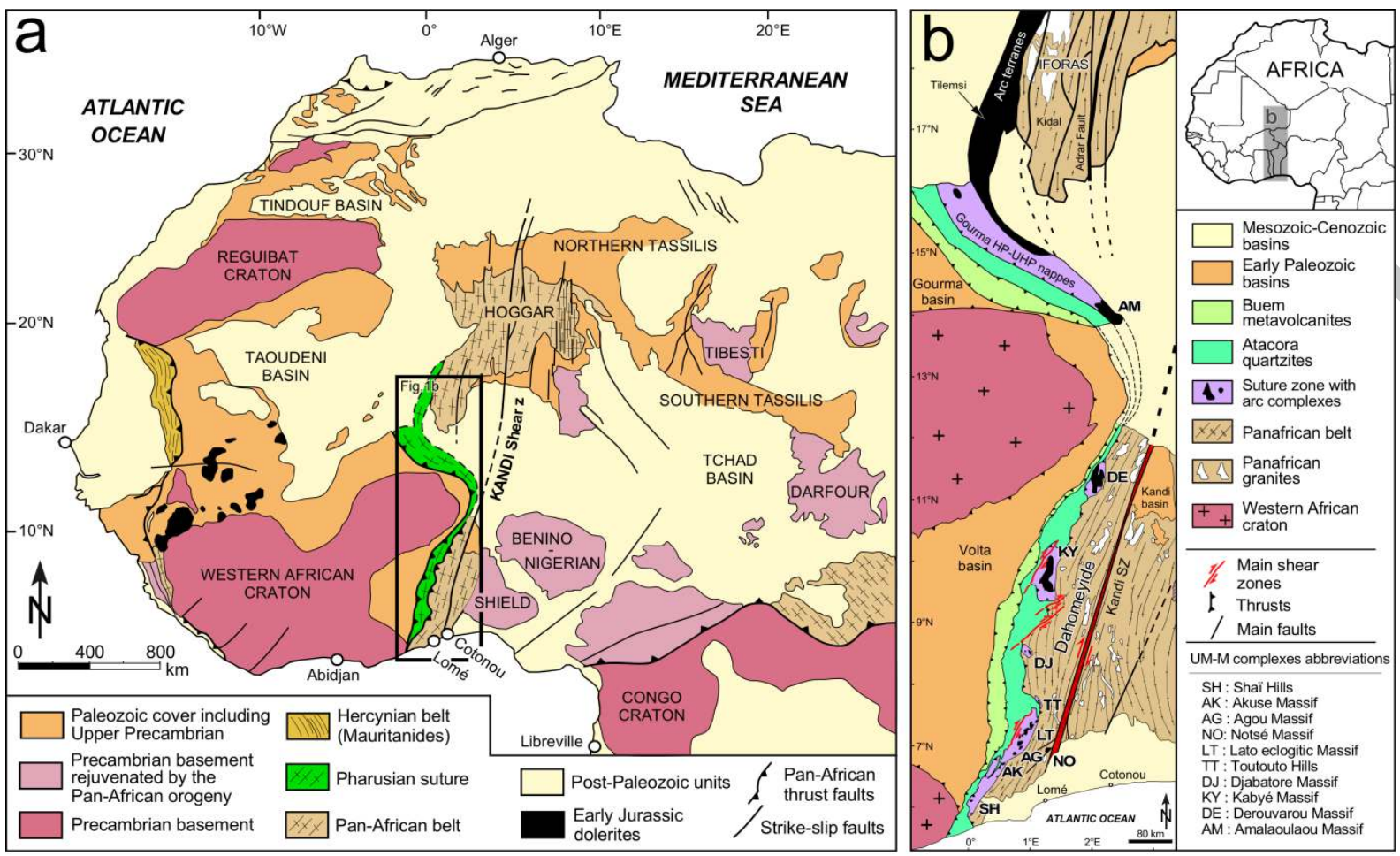

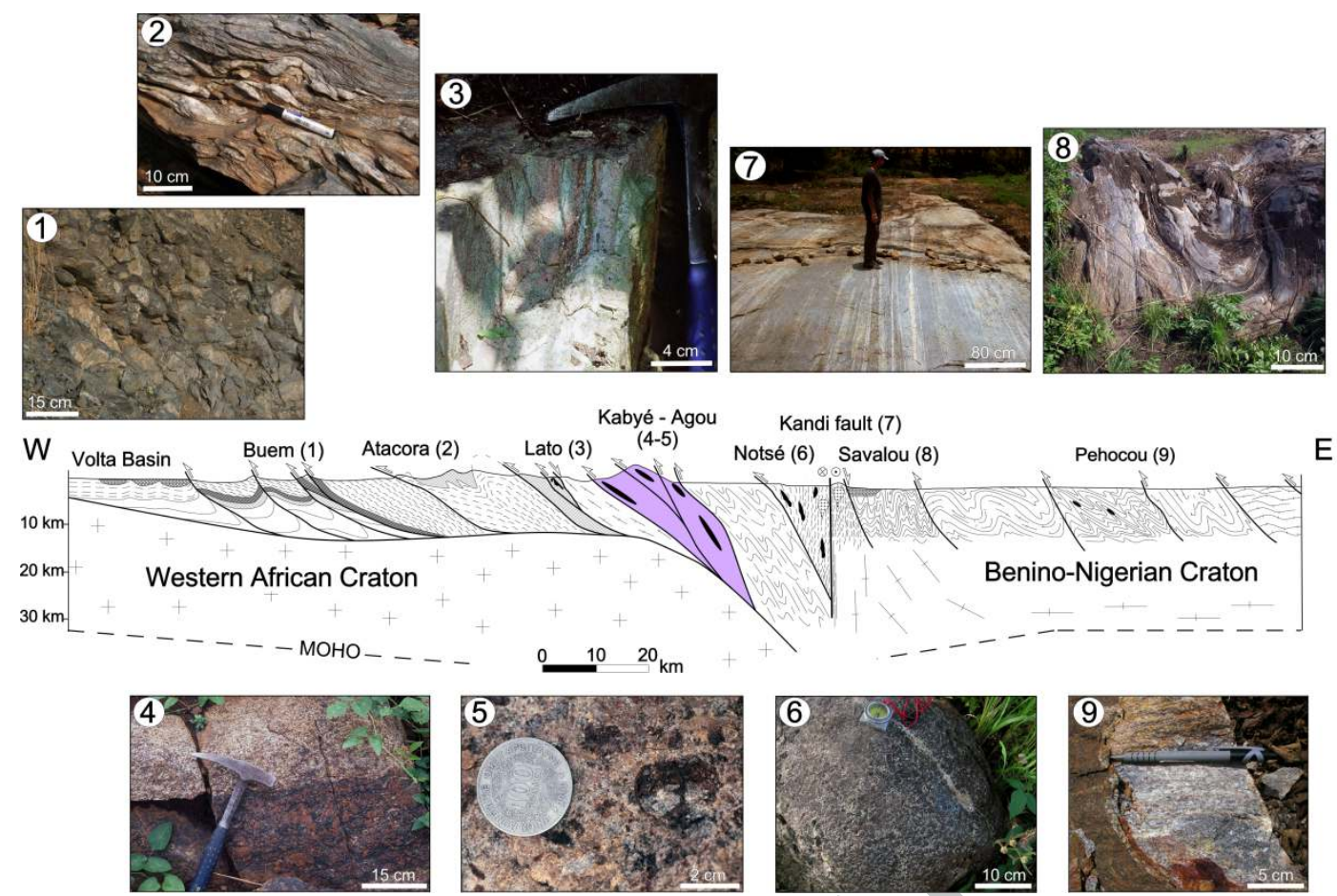

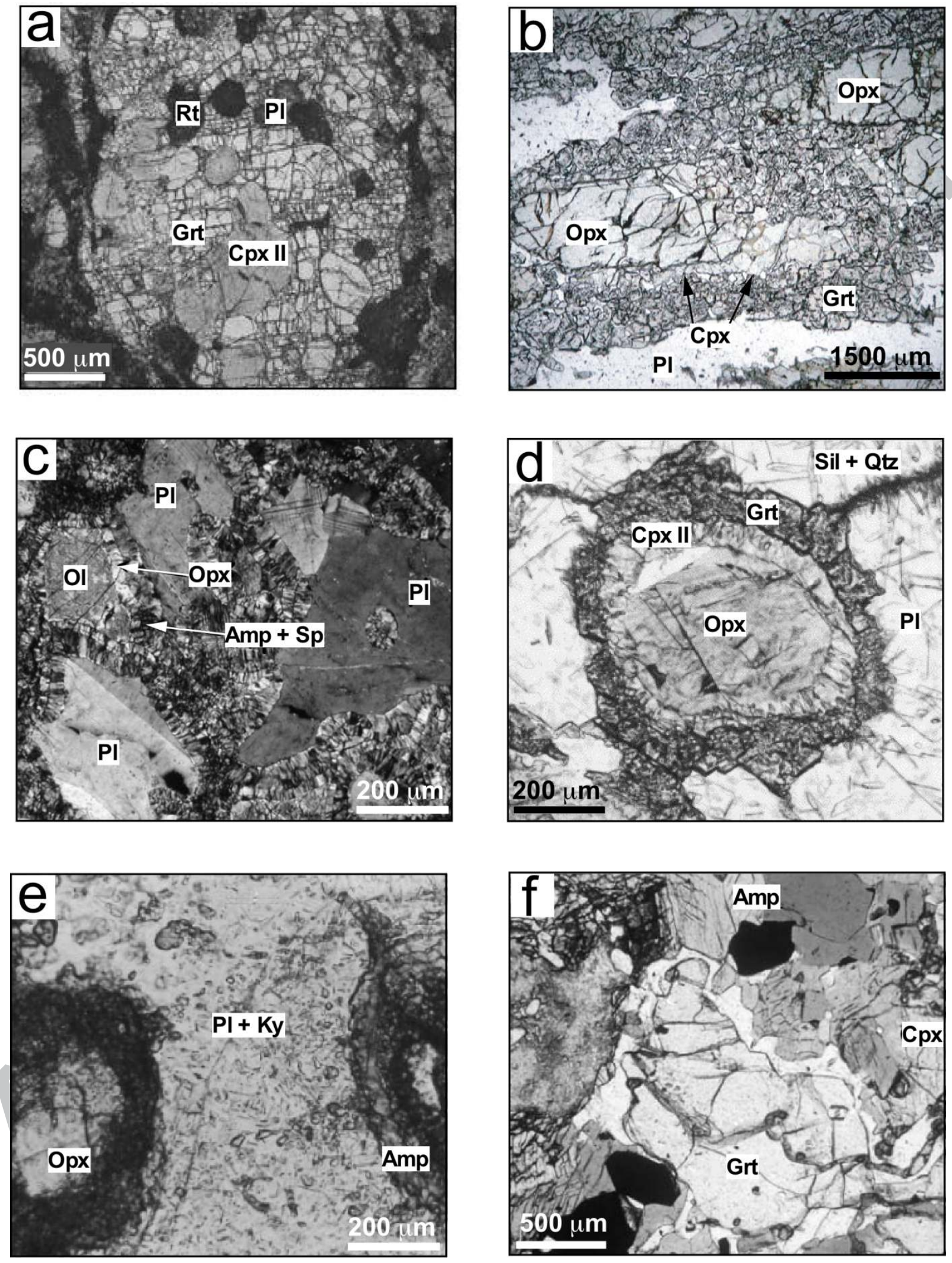


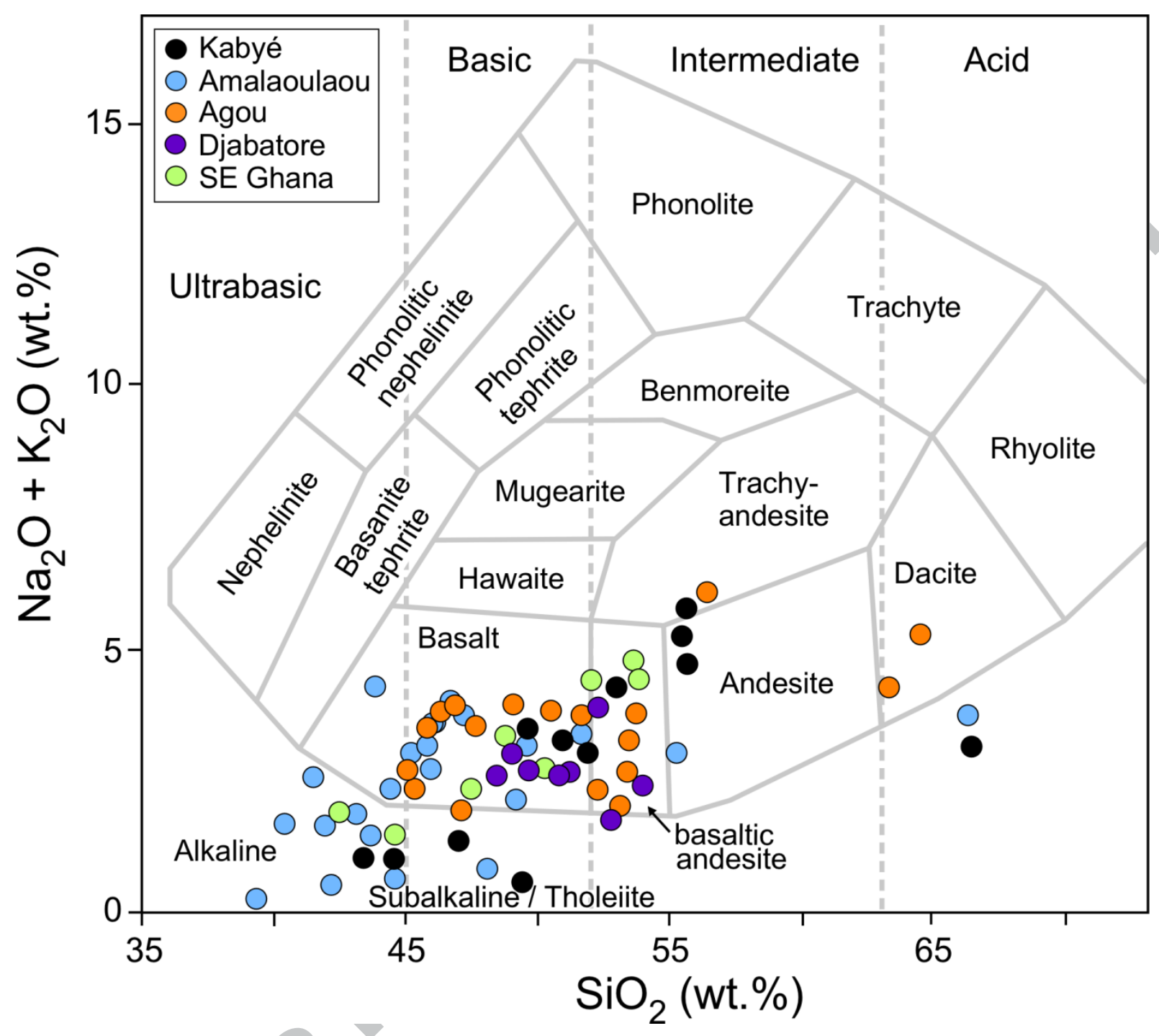




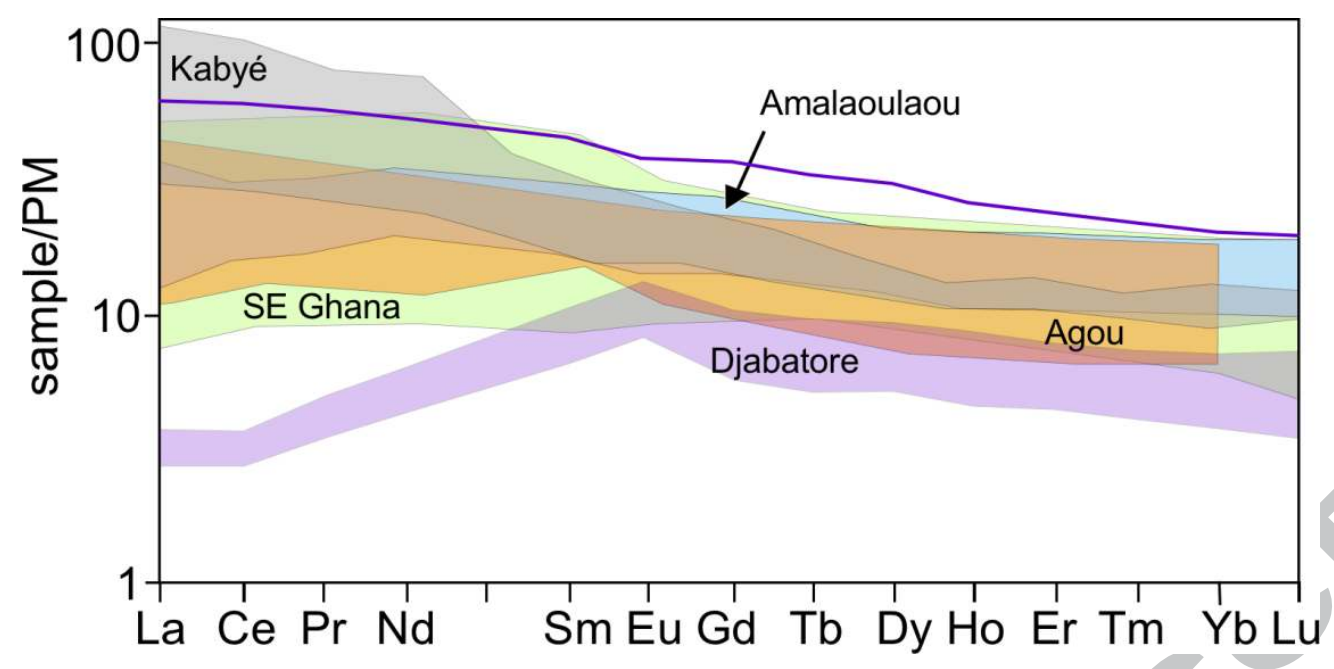




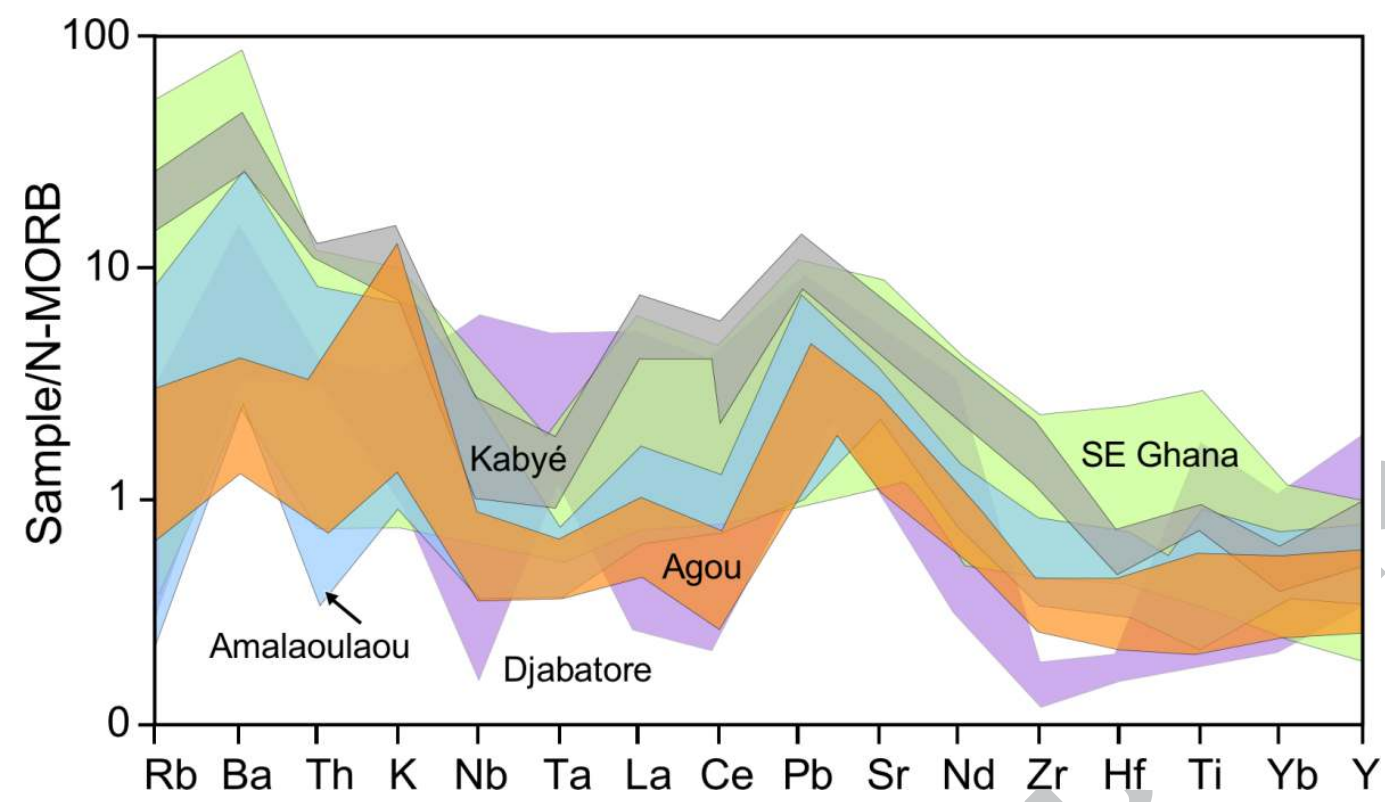




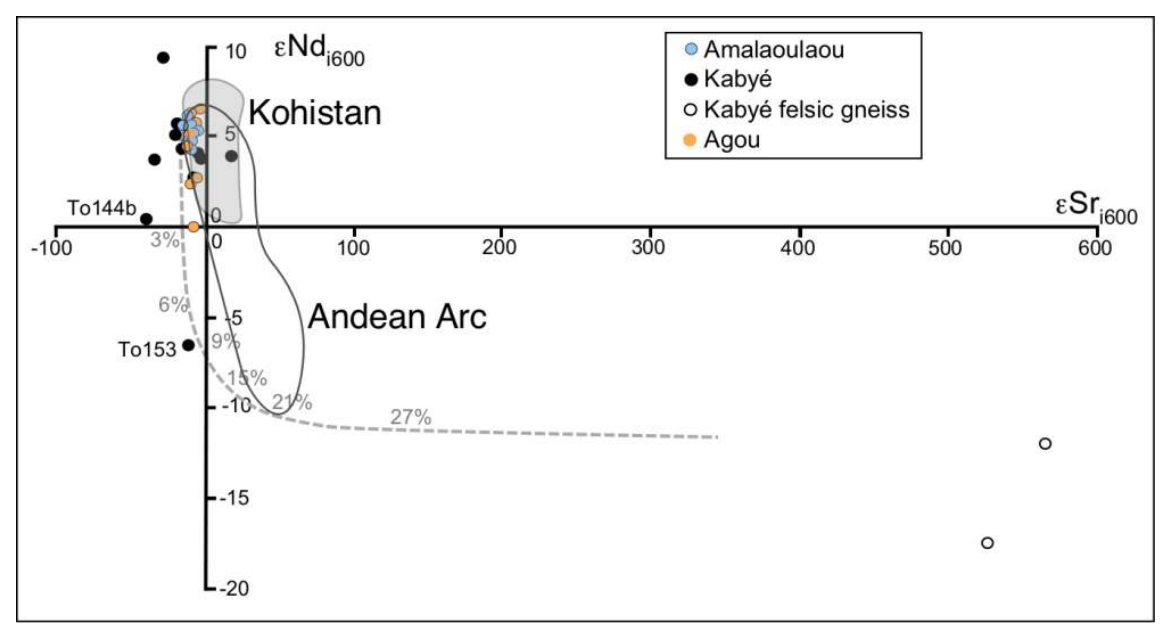




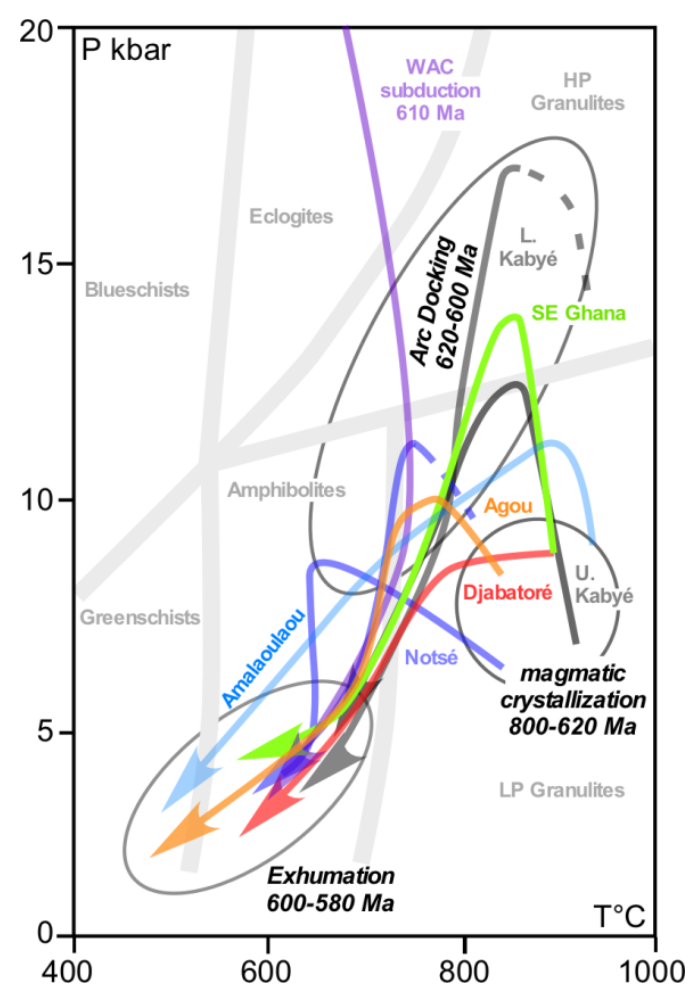




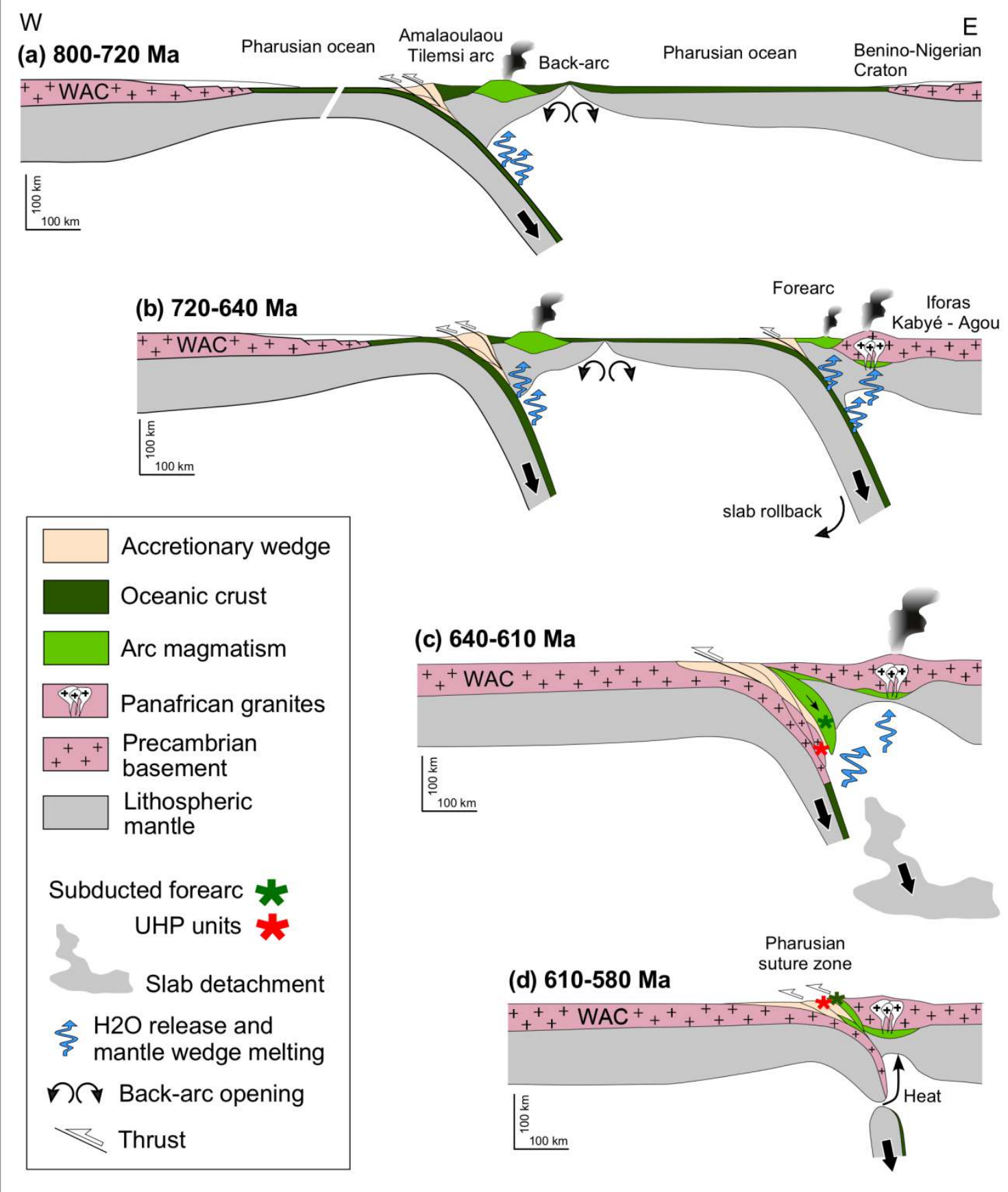




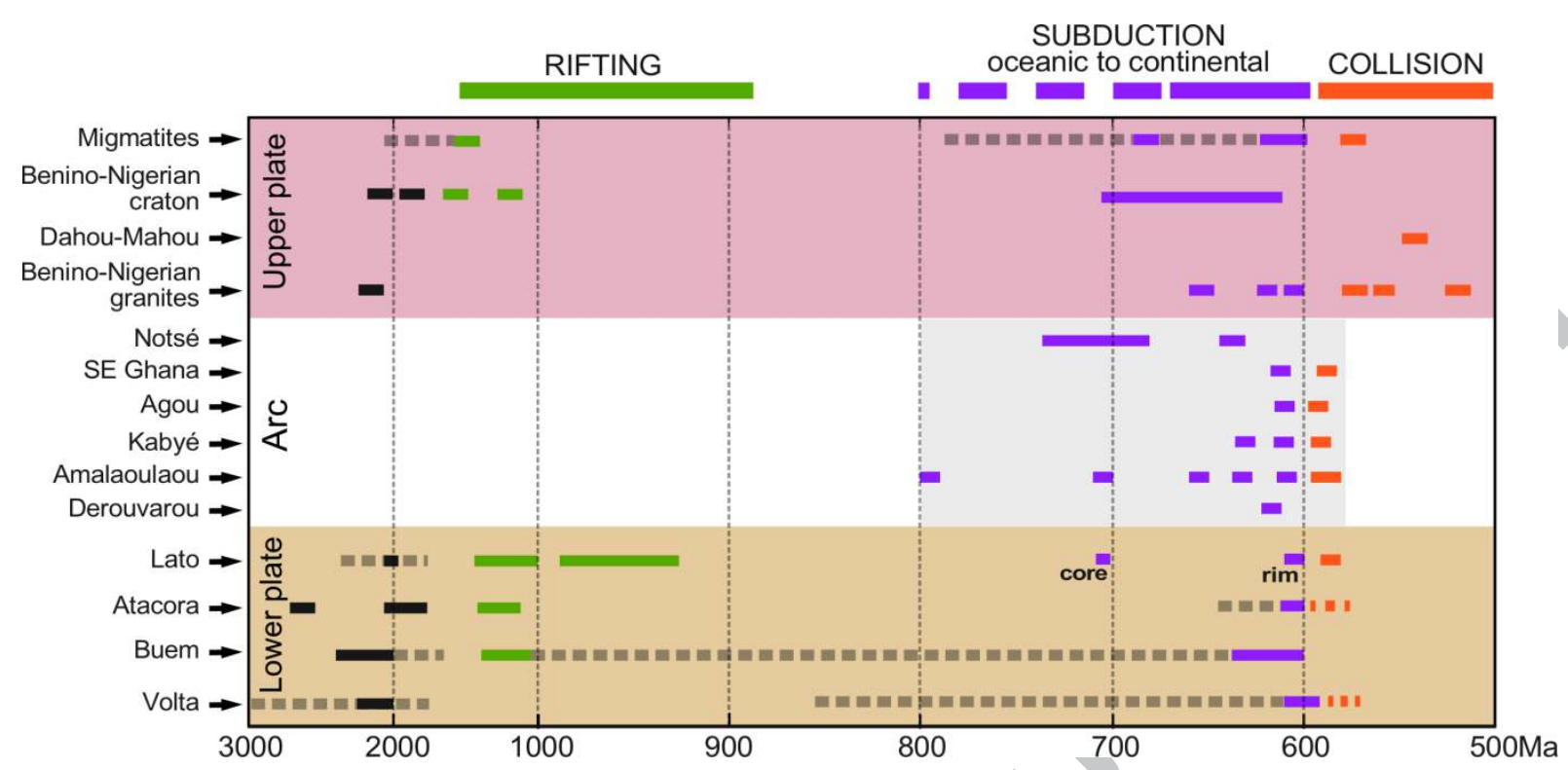




\begin{tabular}{|c|c|c|c|c|}
\hline & Volta basin & Buem & Atacora & \\
\hline Bonhomme, 1962 & & & & Eclogites \\
\hline $\begin{array}{l}\text { Grant, } 1970 \\
\text { Grant et al., } 1972\end{array}$ & & & & \\
\hline Bowden \& Turner, 1974 & & & & \\
\hline Vachette,1975 & & & & \\
\hline Clauer, 1976 & $\begin{array}{l}660+/-9 \mathrm{Ma} \\
\text { (K/Ar musc) }\end{array}$ & & & \\
\hline Affaton et al., 1978 & & & & \\
\hline Caen-Vachette et al., 1979 & & & & \\
\hline $\begin{array}{l}\text { de la Boisse, } 1979 \\
\text { Berger et al., } 2011\end{array}$ & & & & \\
\hline Bowden et al., 1981 & & & & \\
\hline Clauer, 1982 & & $\begin{array}{l}\text { 650Ma }(\mathrm{Rb} / \mathrm{Sr}, \\
\text { glauconite) } \\
\text { 550Ma (K/Ar, illite) }\end{array}$ & & \\
\hline Amard \& Affaton, 1984 & $\begin{array}{l}650+/-20 \mathrm{Ma} \\
\text { (K/Ar, musc) }\end{array}$ & & & \\
\hline Breda, 1985 & & & & \\
\hline Agyei et al., 1987 & & & & \\
\hline Jones, 1990 & & $500 \mathrm{Ma}(\mathrm{K} / \mathrm{Ar}, \mathrm{WR})$ & & \\
\hline $\begin{array}{l}\text { B-Griffiths et al., } 1991 \\
\text { Duclaux et al., } 2006\end{array}$ & & & $\begin{array}{l}608+/-1.2 \mathrm{Ma} \\
(\mathrm{U} / \mathrm{Pb}, \mathrm{Zr})\end{array}$ & $\begin{array}{l}\text { Lato (South-Togo) } \\
638+/ 12 /-53 \mathrm{Ma}(\mathrm{U} / \mathrm{Pb}, \\
\mathrm{Zr}) \\
\\
598+/-12(\mathrm{Rb} / \mathrm{Sr}) \\
571+/-12 \mathrm{Ma}(\mathrm{Ar} / \mathrm{Ar}, \\
\text { pheng) } \\
822+/ 129 /-91 \mathrm{Ma}(\mathrm{U} / \mathrm{Pb}, \\
\mathrm{Zr}) \\
1.15 \mathrm{Ga} \text { (model age, Sm }\end{array}$ \\
\hline $\begin{array}{l}\text { Granade de Arauji et al., } \\
2014\end{array}$ & & & & Lato (South-Togo) \\
\hline
\end{tabular}




\begin{tabular}{|l|l|l|l|l|} 
& & & $608.7+/-5.8(\mathrm{U} / \mathrm{Pb}, \mathrm{Zr})$ \\
\hline $\begin{array}{l}\text { Affaton et } \\
\text { al.,2000 }\end{array}$ & & & & \\
\hline $\begin{array}{l}\text { Attoh et al., 1991 } \\
\text { Attoh et al., 1997 } \\
\text { Hirdes \& Davis, 2002 }\end{array}$ & & & $\begin{array}{l}\text { Kara gneiss } \\
578+/-0.8 \\
\text { (Ar/Ar, musc) }\end{array}$ & \\
\hline & & & & \\
& & & & \\
& & & & \\
Agbossoumondé et al., 2013 & & & & \\
\hline
\end{tabular}

Attoh et al., 2013 


\begin{tabular}{|c|c|c|c|c|c|c|c|}
\hline \multicolumn{2}{|c|}{ Amalaoulalou } & \multicolumn{2}{|l|}{ Kabyé } & \multicolumn{2}{|l|}{ Agou } & \multicolumn{2}{|l|}{$\begin{array}{l}\text { SE } \\
\text { Ghana }\end{array}$} \\
\hline $04-75$ & Epidote Amphibolite & AF6436 & felsic gneiss & ym11 & Metagabbro & $\mathrm{SH} 42$ & Grt Metagabbr \\
\hline IC933 & Epidote Amphibolite & AF6451 & felsic gneiss & Ym25 & Metagabbro & SH67 & Grt Metagabbr \\
\hline IC935.8 & Epidote Amphibolite & K17-1 & Metapyroxenite & A33 & $\begin{array}{l}\text { Metagabbro } \\
\text { Grt }\end{array}$ & SH8 & Metagabbro \\
\hline AJB1 & Metagabbro & $\mathrm{K} 17-4$ & Metagabbro & A19b & $\begin{array}{l}\text { Metagabbro } \\
\text { Grt }\end{array}$ & AD18 & $\mathrm{Hb}$ Metagabbro \\
\hline AJB14 & Metagabbro & $\mathrm{K} 17-12$ & Metagabbro & A16 & $\begin{array}{l}\text { Metagabbro } \\
\text { Grt }\end{array}$ & KB21 & $\mathrm{Hb}$ Metagabbro \\
\hline AJB12 & Grt Metagabbro & K25-5 & Metagabbro & A15b & $\begin{array}{l}\text { Metagabbro } \\
\text { Grt }\end{array}$ & KB25 & $\mathrm{Hb}$ Metagabbro \\
\hline AJN18 & Grt Metagabbro & TO64 & Grt Metapyroxenite & A32 & Metagabbro & RT74 & $\mathrm{Hb}$ Metagabbro \\
\hline AJB25 & Grt Metagabbro & TO66 & Metapyroxenite & A9 & Metagabbro & KB65 & $\mathrm{Hb}$ Metagabbro \\
\hline AJB23 & Grt Metagabbro & TO69 & felsic gneiss & Ym9 & $\begin{array}{l}\text { Amphibolites } \\
\text { Grt }\end{array}$ & & \\
\hline $04-73$ & Grt Metagabbro & TO70 & trondjhemite & & $\begin{array}{l}\text { Amphibolites } \\
\text { Grt }\end{array}$ & & \\
\hline AJB21 & Spinel Pxite & TO72 & Grt Metagabbro & $\mathrm{Ag} 262$ & $\begin{array}{l}\text { Amphibolites } \\
\text { Grt }\end{array}$ & & \\
\hline AJB26 & Spinel Pxite & TO73A & Metapyroxenite & Ag224 & $\begin{array}{l}\text { Metagabbro } \\
\text { Grt }\end{array}$ & & \\
\hline AJB28 & Spinel Pxite & T0101B & Metagabbro & A23 & Metagabbro & & \\
\hline AJB29 & Spinel Pxite & T0106 & Metagabbro & A17 & Metagabbro & & \\
\hline $04-92$ & Grt Pxite & T0107 & Grt Metapyroxenite & Ag319 & metabasalt & & \\
\hline IC9B6b & Grt Pxite & T0125 & Grt Metagabbro & Ym12 & metabasalt & & \\
\hline $04-77$ & Plag Pxite & T0129 & Grt Metagabbro & A2 & metabasalt & & \\
\hline IC944Q & Quartz Gabbro & T0132 & Metapyroxenite & $A 5 b$ & metabasalt & & \\
\hline $04-81$ & Quartz Gabbro & T0135 & felsic gneiss & A7 & metabasalt & & \\
\hline IC952 & Hbl Gabbro & T0136 & felsic gneiss & A25 & metabasalt & & \\
\hline $944 \mathrm{~A}$ & Hbl Gabbro & T0138 & Metagabbro & Ym13 & $\begin{array}{l}\text { metabasalt } \\
\text { Grt }\end{array}$ & & \\
\hline O478 & Trondhjemite & T0139 & Metagabbro & Ym5 & Amphibolites & & \\
\hline IC948 & Tonalite & $\begin{array}{l}\text { T0140 } \\
\text { T0144B } \\
\text { T0153 } \\
\text { T0174 }\end{array}$ & $\begin{array}{l}\text { Metagabbro } \\
\text { Metapyroxenite } \\
\text { Metagabbro } \\
\text { Metapyroxenite }\end{array}$ & $\begin{array}{l}\text { Ym26 } \\
\text { A5a }\end{array}$ & $\begin{array}{l}\text { Metagabbro } \\
\text { metadacite }\end{array}$ & & \\
\hline
\end{tabular}




\begin{tabular}{|c|c|c|c|c|c|c|c|c|c|c|c|}
\hline \multirow{2}{*}{$\begin{array}{l}\text { Massif } \\
\text { Sampl } \\
\mathrm{e}\end{array}$} & \multicolumn{2}{|l|}{ Kabyé } & \multicolumn{2}{|l|}{ Kabyé } & \multicolumn{2}{|l|}{ Kabyé } & \multicolumn{2}{|l|}{ Kabyé } & \multicolumn{2}{|l|}{ Kabyé } & \multirow{2}{*}{$\begin{array}{l}\text { Kabyé } \\
\text { TO72 } \\
\text { b }\end{array}$} \\
\hline & $\begin{array}{l}\text { AF645 } \\
1\end{array}$ & K25-5 & TO62 & $\begin{array}{l}\text { TO6 } \\
4\end{array}$ & TO66 & TO67 & T069 & T070 & TO71 & $\begin{array}{l}\text { TO71 } \\
\mathrm{a}\end{array}$ & \\
\hline $\mathrm{SiO}_{2}$ & 55.88 & 55.58 & 51.47 & $\begin{array}{l}55.9 \\
3\end{array}$ & 44.65 & 49.46 & 66.64 & 49.34 & 49.54 & 53.17 & 51.77 \\
\hline $\mathrm{TiO}_{2}$ & 1.14 & 1.17 & 0.63 & 1.37 & 1.55 & 0.47 & 0.74 & 0.45 & 0.97 & 0.71 & 0.71 \\
\hline $\mathrm{Al}_{2} \mathrm{O}_{3}$ & 16.89 & 17.11 & 17.85 & $\begin{array}{l}16.4 \\
2\end{array}$ & 13.73 & 6.67 & 17.07 & 27.62 & 19.31 & 23.01 & 18.99 \\
\hline $\mathrm{FeOt}$ & 9.24 & 8.46 & 9.03 & 8.57 & 17.44 & 12.18 & 8.59 & 3.44 & 11.03 & 5.73 & 9.68 \\
\hline $\mathrm{MnO}$ & 0.19 & 0.12 & 0.14 & 0.13 & 0.2 & 0.2 & 0.11 & 0.04 & 0.18 & 0.1 & 0.16 \\
\hline $\mathrm{MgO}$ & 4.45 & 4.75 & 7.15 & 4.62 & 10.33 & 18.75 & 3.26 & 1.47 & 5.17 & 1.98 & 5.17 \\
\hline $\mathrm{CaO}$ & 6.78 & 7.37 & 10.05 & 7.11 & 11.7 & 12.17 & 1.27 & 13.63 & 10.17 & 10.37 & 10.06 \\
\hline $\mathrm{Na}_{2} \mathrm{O}$ & 3.66 & 4.17 & 3.1 & 3.58 & 0.93 & 0.44 & 0.95 & 3.15 & 3.08 & 3.87 & 2.71 \\
\hline $\mathrm{K}_{2} \mathrm{O}$ & 1.22 & 1.24 & 0.19 & 1.45 & 0.07 & 0.01 & 2.08 & 0.22 & 0.2 & 0.43 & 0.33 \\
\hline $\mathrm{P}_{2} \mathrm{O}_{5}$ & 0.32 & 0.27 & 0.04 & 0.43 & 0.02 & 0.01 & 0.06 & 0.08 & 0.2 & 0.1 & 0.09 \\
\hline LOI & 0.58 & 0.02 & 0.02 & 0.02 & 0.46 & 0.22 & 0 & 0.16 & 0.03 & 0.63 & 0.18 \\
\hline $\begin{array}{l}\text { Total } \\
\text { (ppm) }\end{array}$ & 100.13 & $\begin{array}{l}100.2 \\
6\end{array}$ & 99.72 & $\begin{array}{l}99.6 \\
8\end{array}$ & $\begin{array}{l}100.2 \\
4\end{array}$ & $\begin{array}{l}100.1 \\
7\end{array}$ & $\begin{array}{l}100.8 \\
4\end{array}$ & 99.65 & 99.94 & $\begin{array}{l}100.1 \\
4\end{array}$ & 99.89 \\
\hline $\mathrm{Ba}$ & 442.00 & $\begin{array}{l}375.0 \\
0\end{array}$ & 95.1 & $\begin{array}{l}579 . \\
8\end{array}$ & 106.6 & 2.9 & 564.6 & 153.1 & 104.4 & 170.4 & 131.4 \\
\hline $\mathrm{Rb}$ & 17.00 & 26.00 & 0.61 & 29 & 1.46 & 0.33 & 39.64 & 1.07 & 2.04 & 4 & 3.83 \\
\hline $\mathrm{Sr}$ & 407.00 & $\begin{array}{l}520.0 \\
0\end{array}$ & 482.1 & $\begin{array}{l}511 . \\
3\end{array}$ & 31.7 & 26.4 & 72.1 & $\begin{array}{l}1167 . \\
1\end{array}$ & 351.1 & 380.6 & 323.8 \\
\hline Y & 34.00 & 17.00 & 5.91 & $\begin{array}{l}16.0 \\
8\end{array}$ & 25.41 & 6.96 & 21.64 & 2.81 & 8.34 & 8.03 & 9.84 \\
\hline $\mathrm{Zr}$ & 215.00 & $\begin{array}{l}136.0 \\
0\end{array}$ & 12.82 & $\begin{array}{l}46.1 \\
8\end{array}$ & 92.75 & 7.8 & $\begin{array}{l}111.4 \\
9\end{array}$ & 11.57 & 13.49 & 18.49 & 16.4 \\
\hline $\mathrm{Nb}$ & 9.00 & 3.00 & 1.14 & 8.98 & 11.46 & 0.58 & 8.83 & 1.26 & 1.95 & 2.35 & 2.56 \\
\hline Th & - & - & & 2 & & & 4.49 & 0.24 & 0.1 & 1.1 & 0.5 \\
\hline $\mathrm{Pb}$ & - & 7.00 & 1.47 & 9.23 & 0.75 & & 1.48 & 2.26 & 1.8 & 4.71 & 3.74 \\
\hline $\mathrm{Cu}$ & 111.00 & $\begin{array}{l}206.0 \\
0\end{array}$ & 24.3 & $\begin{array}{l}163 . \\
8\end{array}$ & 168.7 & 15.6 & 18.9 & 51.4 & 62.3 & 65.5 & 72.8 \\
\hline $\mathrm{Ni}$ & 30.00 & 59.7 & 80 & 71.3 & 103.4 & 287.2 & 47.8 & 11.9 & 16 & 7.4 & 21.4 \\
\hline V & 177.00 & 196.8 & 177.9 & 186 & 473.5 & 301.2 & 79.1 & 82.8 & 266.1 & 135.8 & 154.9 \\
\hline $\mathrm{Cr}$ & 61.00 & & 163.7 & $\begin{array}{l}102 . \\
5\end{array}$ & 162.8 & 649.3 & 111.5 & 14.9 & 38.3 & 16.8 & 58.4 \\
\hline $\mathrm{Hf}$ & - & & 0.39 & 1.23 & 2.99 & 0.48 & 2.86 & 0.27 & 0.29 & 0.44 & 0.81 \\
\hline $\mathrm{Sc}$ & 24.00 & 18.4 & 23.35 & $\begin{array}{l}17.1 \\
9\end{array}$ & 50.99 & 50.42 & 14.35 & 6.97 & 24.21 & 12.41 & 26.43 \\
\hline Co & 115.00 & 32.3 & 37.1 & 29.4 & 54.8 & 71 & 16.3 & 11.5 & 35 & 14.4 & 29.3 \\
\hline U & - & - & & 0.49 & 0.24 & & 1.01 & & & 0.59 & 0.32 \\
\hline La & - & 14.6 & 3.45 & $\begin{array}{l}27.1 \\
2\end{array}$ & 5.06 & 0.57 & 37.21 & 4.23 & 4.61 & 6.02 & 5.71 \\
\hline $\mathrm{Ce}$ & - & 42.1 & 7.85 & $\begin{array}{l}64.8 \\
2\end{array}$ & 21.23 & 2.05 & 72.1 & 9.81 & 11.12 & 12.77 & 12.98 \\
\hline $\mathrm{Nd}$ & - & 22.4 & 4.34 & $\begin{array}{l}35.4 \\
1\end{array}$ & 22.86 & 2.76 & 24.79 & 4.96 & 6.6 & 5.79 & 7.39 \\
\hline Sm & - & 4.9 & 1.1 & 6.04 & 6.55 & 1.05 & 4.89 & 0.8 & 1.69 & 1.22 & 1.81 \\
\hline $\mathrm{Eu}$ & - & 1.3 & 0.66 & 1.74 & 1.79 & 0.48 & 1.68 & 0.66 & 0.82 & 0.92 & 0.88 \\
\hline $\mathrm{Gd}$ & - & 4.5 & 1.16 & 5.01 & 5.09 & 1.08 & 4.29 & 0.69 & 1.62 & 1.35 & 1.47 \\
\hline $\mathrm{Tb}$ & - & - & 0.22 & 0.77 & 1.2 & 0.29 & 0.85 & 0.1 & 0.34 & 0.3 & 0.39 \\
\hline Dy & - & 3.8 & 1.24 & 3.76 & 6.26 & 1.6 & 4.38 & 0.62 & 1.66 & 1.58 & 2.12 \\
\hline Ho & - & - & 0.28 & 0.71 & 1.11 & 0.33 & 0.91 & 0.1 & 0.38 & 0.28 & 0.47 \\
\hline $\mathrm{Er}$ & - & 1.9 & 0.64 & 1.89 & 2.68 & 0.92 & 2.96 & 0.32 & 0.96 & 1.09 & 1.31 \\
\hline $\mathrm{Tm}$ & - & - & & 0.24 & 0.35 & 0.17 & 0.45 & & 0.18 & 0.2 & 0.24 \\
\hline $\mathrm{Yb}$ & - & 1.6 & 0.71 & 1.47 & 1.91 & 0.89 & 2.41 & 0.27 & 0.88 & 1.01 & 1.22 \\
\hline Lu & - & - & & 0.24 & 0.26 & & 0.39 & & & & 0.19 \\
\hline $\mathrm{Zr}$ & & 136.0 & 12.82 & 46.1 & 92.75 & 7.8 & 111.4 & 11.57 & 13.49 & 18.49 & 16.4 \\
\hline
\end{tabular}


0

8

9

\begin{tabular}{|c|c|c|c|c|c|c|c|c|c|c|c|}
\hline Massif & Kabyé & & Kabyé & & Kabyé & & Amalac & & $\begin{array}{l}\text { Amalao } \\
\mathrm{u}\end{array}$ & & $\begin{array}{l}\text { Amalao } \\
\mathrm{u}\end{array}$ \\
\hline $\begin{array}{l}\text { Sampl } \\
\mathrm{e}\end{array}$ & $\begin{array}{l}\text { TO73 } \\
\mathrm{a}\end{array}$ & $\begin{array}{l}\text { TO73 } \\
\mathrm{c}\end{array}$ & TO73d & $\begin{array}{l}\text { AF643 } \\
6\end{array}$ & $\begin{array}{l}\text { AF643 } \\
7\end{array}$ & $\begin{array}{l}\text { AF643 } \\
8\end{array}$ & AJB 1 & $\begin{array}{l}\text { AJB } \\
14\end{array}$ & 04-73 & $\begin{array}{l}\text { AJB } \\
3\end{array}$ & AJB12 \\
\hline $\mathrm{SiO}_{2}$ & 46.94 & 43.68 & 44.42 & 55.38 & 55.68 & 53.22 & 46.19 & $\begin{array}{l}46.9 \\
6\end{array}$ & 45.87 & $\begin{array}{l}44.3 \\
8\end{array}$ & 42.87 \\
\hline $\mathrm{TiO}_{2}$ & 0.33 & 0.47 & 0.44 & 1.1 & 0.9 & 1.07 & 1.41 & 1.01 & 1.53 & 1.68 & 1.06 \\
\hline $\mathrm{Al}_{2} \mathrm{O}_{3}$ & 15.75 & 18.42 & 16.25 & 18.44 & 18.57 & 18.61 & 17.57 & $\begin{array}{l}19.8 \\
4\end{array}$ & 17.72 & $\begin{array}{l}17.7 \\
5\end{array}$ & 15.53 \\
\hline FeOt & 12.43 & 15.13 & 13.56 & 5.57 & 7.07 & 9.21 & 10.6 & 9.08 & 11.65 & & 12.85 \\
\hline $\mathrm{MnO}$ & 0.2 & 0.28 & 0.21 & 0.12 & 0.13 & 0.18 & 0.14 & 0.14 & 0.2 & 0.23 & 0.23 \\
\hline $\mathrm{MgO}$ & 10.33 & 9.16 & 9.47 & 3.87 & 3.68 & 4.68 & 7.03 & 5.49 & 6.89 & 6.89 & 11.44 \\
\hline $\mathrm{CaO}$ & 12.21 & 12.19 & 13.1 & 8.1 & 7.37 & 8.17 & 11.02 & $\begin{array}{l}10.7 \\
5\end{array}$ & 11.77 & $\begin{array}{l}11.5 \\
5\end{array}$ & 11.46 \\
\hline $\mathrm{Na}_{2} \mathrm{O}$ & 1.27 & 0.93 & 1.39 & 4.24 & 4.64 & 3.65 & 3.66 & 3.66 & 2.72 & 2.35 & 1.76 \\
\hline $\mathrm{K}_{2} \mathrm{O}$ & 0.09 & 0.07 & 0.11 & 0.88 & 0.83 & 0.53 & 0.2 & 0.13 & 0.1 & 0.11 & 0.15 \\
\hline $\mathrm{P}_{2} \mathrm{O}_{5}$ & 0.02 & 0.02 & 0.02 & 0.15 & 0.23 & 0.23 & 0.23 & 0.18 & 0.28 & 0.28 & 0.08 \\
\hline LOI & 0.21 & -0.1 & 0.16 & 0.46 & 0.93 & 0.53 & 1.47 & 1.66 & 0.78 & 0.75 & 1.3 \\
\hline $\begin{array}{l}\text { Total } \\
\text { (ppm) }\end{array}$ & 99.82 & $\begin{array}{l}100.2 \\
9\end{array}$ & 99.16 & 100.31 & 100.03 & 100.09 & & 98.9 & 99.49 & $\begin{array}{l}99.2 \\
8\end{array}$ & 98.73 \\
\hline $\mathrm{Ba}$ & 7.7 & 17.8 & 13.7 & 279 & 319 & 226 & 54.8 & 55.5 & 46.3 & 39.6 & 83.6 \\
\hline $\mathrm{Rb}$ & 0.58 & 1.16 & 0.85 & 4 & 12 & 2 & 0.53 & 0.68 & 0.42 & 1.08 & 0.45 \\
\hline $\mathrm{Sr}$ & 38.4 & 80.1 & 61.7 & 495 & 488 & 446 & 446.7 & $\begin{array}{l}537 . \\
3\end{array}$ & 412.9 & $\begin{array}{l}381 . \\
5\end{array}$ & 206.5 \\
\hline Y & 5 & 7.75 & 5.35 & 18 & 14 & 20 & 22.4 & 19.5 & 29.2 & 31.3 & 26.1 \\
\hline $\mathrm{Zr}$ & 6.99 & 10.39 & 9.98 & 126 & 103 & 125 & 104.6 & 78.6 & 54.1 & 62.3 & 35.1 \\
\hline $\mathrm{Nb}$ & 1.36 & 1.88 & 1.24 & & 5 & 6 & 2.98 & 2.51 & 2.84 & 2.24 & 1.52 \\
\hline Th & & 0.27 & 0.47 & & & & & & 0.15 & 0.35 & 0.07 \\
\hline $\mathrm{Pb}$ & 0.25 & 0.46 & 0.25 & & & & 0.77 & 1.33 & 0.98 & 0.89 & 0.61 \\
\hline $\mathrm{Cu}$ & 73.7 & 190.8 & 21.3 & 61 & 25 & 41 & $\begin{array}{l}103.0 \\
0\end{array}$ & 60 & 51 & 72 & 22 \\
\hline $\mathrm{Ni}$ & 138.9 & 66.5 & 97.5 & 15 & 25 & 16 & 65.00 & 57 & 36 & 25 & 166 \\
\hline V & 307.5 & 315.7 & 332.3 & 181 & 150 & 171 & & & & & \\
\hline $\mathrm{Cr}$ & 486.7 & 229.9 & 336.5 & 15 & 43 & 26 & 168 & 121 & 148 & 89 & 547 \\
\hline $\mathrm{Hf}$ & 0.47 & 0.47 & 0.37 & & & & 2.58 & 1.75 & 1.73 & 1.7 & 0.93 \\
\hline Sc & 38.08 & 47.22 & 36.66 & 20 & 20 & 23 & 42 & 28 & 45 & 48 & 50 \\
\hline Co & 50.1 & 51.6 & 50.6 & 68 & 49 & 79 & 54 & 40 & 49 & 54 & 57 \\
\hline $\mathrm{La}$ & 0.98 & 1.91 & 3.05 & & & & 3.22 & 3.37 & 5.17 & 3.88 & 4.74 \\
\hline $\mathrm{Ce}$ & 2.17 & 2.86 & 5.72 & & & & 10.31 & 9.01 & 16.78 & $\begin{array}{l}13.0 \\
0\end{array}$ & 10.8 \\
\hline $\mathrm{Nd}$ & 1.63 & 1.69 & 2.81 & & & & 12.56 & 9.78 & 15.03 & 12.4 & 10.47 \\
\hline Sm & 0.5 & 0.8 & 0.7 & & & & 3.72 & 2.84 & 4.41 & 3.96 & 3.02 \\
\hline $\mathrm{Eu}$ & 0.4 & 0.44 & 0.39 & & & & 1.37 & 1.08 & 1.51 & 1.45 & 1.14 \\
\hline $\mathrm{Gd}$ & 0.53 & 0.95 & 1.33 & & & & 4.51 & 3.5 & 4.99 & 4.73 & 3.6 \\
\hline $\mathrm{Tb}$ & 0.2 & 0.28 & 0.16 & & & & & & & & \\
\hline Dy & 1.09 & 1.56 & 1.15 & & & & 4.65 & 3.8 & 5.04 & 5.16 & 3.83 \\
\hline Ho & 0.22 & 0.34 & 0.22 & & & & 0.86 & 0.7 & 1.03 & 1.06 & 0.83 \\
\hline $\mathrm{Er}$ & 0.7 & 0.93 & 0.62 & & & & 2.36 & 1.97 & 2.91 & 3.01 & 2.38 \\
\hline $\mathrm{Tm}$ & 0.15 & 0.17 & & & & & & & & & \\
\hline $\mathrm{Yb}$ & 0.61 & 0.86 & 0.62 & & & & 2.13 & 1.84 & 2.74 & 2.98 & 2.42 \\
\hline Lu & & & & & & & 0.26 & 0.23 & 0.41 & 0.46 & 0.38 \\
\hline $\mathrm{Zr}$ & 6.99 & 10.39 & 9.98 & 126 & 103 & 125 & 104.6 & 78.6 & 54.1 & 62.3 & 35.1 \\
\hline
\end{tabular}




\begin{tabular}{|c|c|c|c|c|c|c|c|c|c|c|c|}
\hline Massif & $\begin{array}{l}\text { Amalao } \\
\mathrm{u}\end{array}$ & & $\begin{array}{l}\text { Amalao } \\
\mathrm{u}\end{array}$ & & Amala & & Amala & & $\begin{array}{l}\text { Amalao } \\
\mathrm{u}\end{array}$ & & $\begin{array}{l}\text { Amalao } \\
\mathrm{u}\end{array}$ \\
\hline $\begin{array}{l}\text { Sampl } \\
\text { e }\end{array}$ & AJB 18 & $\begin{array}{l}\text { AJB } \\
25\end{array}$ & AJB 23 & $\begin{array}{l}04- \\
92\end{array}$ & $\begin{array}{l}\text { AJB2 } \\
6\end{array}$ & $\begin{array}{l}04- \\
77 \mathrm{~b}\end{array}$ & $\begin{array}{l}\text { AJB2 } \\
1\end{array}$ & $\begin{array}{l}\text { AJB2 } \\
9\end{array}$ & $04-75$ & $\begin{array}{l}\text { IC } \\
935.8\end{array}$ & IC 933 \\
\hline $\mathrm{SiO}_{2}$ & 45.88 & 45.18 & 41.89 & 47.93 & 40.21 & 44.49 & 42.27 & 39.25 & 41.37 & 43.58 & 43.72 \\
\hline $\mathrm{TiO}_{2}$ & 1.43 & 1.16 & 0.73 & 0.89 & 1.62 & 0.64 & 0.57 & 0.52 & 1.95 & 0.44 & 3.12 \\
\hline $\mathrm{Al}_{2} \mathrm{O}_{3}$ & 16.67 & 17.44 & 18.86 & 9.71 & 17.9 & 13.15 & 14.11 & 17.42 & 16.87 & 18.21 & 12.91 \\
\hline FeOt & 10.66 & 10.81 & 10.98 & 9.11 & 13.81 & 11.25 & 9.69 & 11.25 & 12.5 & 11.93 & 13.67 \\
\hline $\mathrm{MnO}$ & 0.16 & 0.16 & 0.16 & 0.12 & 0.21 & 0.18 & 0.15 & 0.16 & 0.16 & 0.19 & 0.18 \\
\hline $\mathrm{MgO}$ & 7.69 & 7.79 & 10.49 & 11.58 & 7.00 & 13.33 & 15.01 & 15.34 & 8.33 & 8.24 & 9.02 \\
\hline $\mathrm{CaO}$ & 10.71 & 12.38 & 13.22 & 20.33 & 14.62 & 15.01 & 17.25 & 15.55 & 12.76 & 13.38 & 10.26 \\
\hline $\mathrm{Na}_{2} \mathrm{O}$ & 3.39 & 2.9 & 1.43 & 0.93 & 1.55 & 0.74 & 0.58 & 0.34 & 2.55 & 1.32 & 2.99 \\
\hline $\mathrm{K}_{2} \mathrm{O}$ & 0.21 & 0.15 & 0.34 & 0.04 & 0.21 & 0.07 & 0.02 & 0.03 & 0.18 & 0.15 & 1.38 \\
\hline $\mathrm{P}_{2} \mathrm{O}_{5}$ & 0.2 & 0.15 & & & 0.14 & 0.05 & 0.03 & 0.04 & 0.29 & & 0.98 \\
\hline LOI & 2.27 & 1.25 & 1.58 & 0.21 & 2.19 & 1.75 & 0.59 & 0.71 & 1.63 & 1.57 & 2.02 \\
\hline $\begin{array}{l}\text { Total } \\
\text { (ppm) }\end{array}$ & 99.26 & 99.39 & 99.66 & $\begin{array}{l}100.8 \\
6\end{array}$ & 99.45 & $\begin{array}{l}100.6 \\
7\end{array}$ & $\begin{array}{l}100.2 \\
7\end{array}$ & $\begin{array}{l}100.6 \\
2\end{array}$ & 98.58 & 99.02 & 100.24 \\
\hline $\mathrm{Ba}$ & 70.9 & 65.5 & 60.4 & 5.7 & 114.2 & 12.7 & 2.5 & 187.9 & 62.00 & 44.00 & 76.00 \\
\hline $\mathrm{Rb}$ & 0.31 & 1.47 & 8.62 & 0.81 & 0.65 & 0.57 & 0.36 & & 331.1 & $\begin{array}{l}365.0 \\
0\end{array}$ & 557.3 \\
\hline $\mathrm{Sr}$ & 347.9 & $\begin{array}{l}370.0 \\
0\end{array}$ & 265.7 & 58.3 & 950.4 & 294.2 & 37.6 & 28.2 & 19.00 & 10.6 & 23.7 \\
\hline $\mathrm{Y}$ & 23.2 & 18.00 & 9.5 & 8.9 & 40.6 & 8.1 & 12.5 & 22.1 & 58.8 & 13.6 & 134.2 \\
\hline $\mathrm{Zr}$ & 67.4 & 79.3 & 19.00 & 29.5 & 78.8 & 11.3 & 13.8 & 7.5 & & & \\
\hline $\mathrm{Nb}$ & 3.7 & 1.67 & 0.27 & 0.13 & 2.51 & 0.12 & 0.07 & 0.04 & 23.1 & 17.7 & 313.5 \\
\hline Th & 0.07 & & & & 0.05 & 0.21 & 0.19 & 0.14 & 0.01 & 0.01 & 6.5 \\
\hline $\mathrm{Pb}$ & 0.91 & 0.57 & 0.24 & 0.16 & 3.15 & & & & 0.43 & 0.75 & 3.33 \\
\hline $\mathrm{Cu}$ & 42 & 33 & 50 & & 34 & 200 & 120 & 96 & 93 & 62 & 179 \\
\hline $\begin{array}{l}\mathrm{Ni} \\
\mathrm{V}\end{array}$ & 94 & 30 & 43 & 113 & 24 & 114 & 298 & 128 & 37 & 49 & 23 \\
\hline $\mathrm{Cr}$ & 158 & 196 & 193 & 600 & 12 & 349 & 435 & 101 & 26 & 13 & 52 \\
\hline $\mathrm{Hf}$ & 1.85 & 1.9 & 0.67 & 1.12 & 2.01 & 0.47 & 0.61 & 0.4 & 1.95 & 0.43 & 2.19 \\
\hline Sc & 37 & 43 & 47 & 66 & 56 & 66 & & & 93 & 67 & 123 \\
\hline $\begin{array}{l}\text { Co } \\
U\end{array}$ & 40 & 47 & 57 & 46 & 43 & 63 & 75 & 77 & 182 & 140 & 419 \\
\hline La & 4.64 & 2.25 & 0.47 & 0.5 & 3.79 & 0.99 & 0.92 & 2.31 & 3.06 & 0.38 & 45.64 \\
\hline $\mathrm{Ce}$ & 13.93 & 7.31 & 1.62 & 2.00 & 13.51 & 2.91 & 3.23 & 1.27 & 10.66 & 1.45 & 83.4 \\
\hline $\mathrm{Nd}$ & 12.06 & 9.84 & 3.03 & 4.73 & 14.74 & 3.06 & 3.81 & 4.64 & 15.23 & 3.65 & 52.69 \\
\hline $\mathrm{Sm}$ & 3.57 & 2.82 & 1.25 & 1.85 & 4.77 & 1.16 & 1.5 & 1.51 & 4.19 & 1.29 & 9.86 \\
\hline $\mathrm{Eu}$ & 1.31 & 1.05 & 0.5 & 0.68 & 1.78 & 0.48 & 0.56 & 0.59 & 1.38 & 0.59 & 2.95 \\
\hline $\begin{array}{l}\mathrm{Gd} \\
\mathrm{Tb}\end{array}$ & 3.99 & 3.35 & 1.64 & 2.35 & 5.77 & 1.47 & 1.98 & 2.6 & 4.71 & 1.77 & 9.77 \\
\hline Dy & 4.01 & 3.58 & 2.05 & 2.33 & 6.66 & 1.53 & 2.23 & 2.56 & 4.22 & 2.14 & 5.98 \\
\hline Ho & 0.8 & 0.66 & 0.38 & 0.38 & 1.42 & 0.31 & 0.46 & 0.57 & 0.7 & 0.4 & 0.9 \\
\hline
\end{tabular}

\begin{tabular}{|c|c|c|c|c|c|c|c|c|c|c|c|}
\hline \multirow{2}{*}{$\begin{array}{l}\text { Massif } \\
\text { Sampl } \\
\mathrm{e}\end{array}$} & \multicolumn{2}{|c|}{ Amalaoulaou } & \multicolumn{2}{|c|}{ Amalaoulaou } & \multicolumn{2}{|c|}{ Amalaoulaou } & \multicolumn{2}{|c|}{ SE Ghana } & \multicolumn{2}{|c|}{ SE Ghana } & \multirow{2}{*}{$\begin{array}{l}\text { SE } \\
\text { Ghan } \\
\text { a } \\
\text { SH42 }\end{array}$} \\
\hline & $\begin{array}{l}\text { IC } \\
944 Q \\
\end{array}$ & $04-81$ & IC 944A & $\begin{array}{l}\text { IC } \\
952 \\
\end{array}$ & $\begin{array}{l}\text { IC } \\
948 \\
\end{array}$ & $04-78$ & $\mathrm{SH} 8$ & AD18 & KB21 & $\mathrm{HZ25}$ & \\
\hline $\mathrm{SiO}_{2}$ & 49.13 & 55.2 & 45.64 & 49.47 & 66.3 & 77.56 & 42.4 & 47.4 & 53.87 & 44.4 & 52.03 \\
\hline $\mathrm{TiO}_{2}$ & 0.66 & 0.6 & 0.91 & 1.64 & 0.37 & 0.07 & 3.38 & 1.27 & 0.92 & 1.04 & 0.97 \\
\hline $\mathrm{Al}_{2} \mathrm{O}_{3}$ & 12.74 & 15.36 & 14.7 & 15.07 & 13.65 & 13.08 & 8.66 & 14.6 & 17.61 & 18.2 & 18.3 \\
\hline
\end{tabular}




\begin{tabular}{|c|c|c|c|c|c|c|c|c|c|c|c|}
\hline FeOt & 12.17 & 8.73 & 11.28 & 13.57 & 6.23 & 0.64 & 16.8 & 10.2 & 7.3 & 11.5 & 7.89 \\
\hline $\mathrm{MnO}$ & 0.2 & 0.14 & 0.18 & 0.21 & 0.1 & 0.01 & 0.2 & 0.18 & 0.11 & 0.17 & 0.13 \\
\hline $\mathrm{MgO}$ & 7.95 & 5.97 & 9.5 & 4.46 & 1.83 & 0.23 & 11.6 & 6.32 & 5.55 & 7.94 & 5.41 \\
\hline $\mathrm{CaO}$ & 10.92 & 8.94 & 11.38 & 9.05 & 5.43 & 2.32 & 11.1 & 15.6 & 8.23 & 13.2 & 8.57 \\
\hline $\mathrm{Na}_{2} \mathrm{O}$ & 1.63 & 2.68 & 2.33 & 2.85 & 3.68 & 4.97 & 1.78 & 2.25 & 4.05 & 1.52 & 4.15 \\
\hline $\mathrm{K}_{2} \mathrm{O}$ & 0.61 & 0.38 & 0.87 & 0.44 & 0.16 & 0.84 & 0.3 & 0.26 & 0.57 & 0.1 & 0.44 \\
\hline $\mathrm{P}_{2} \mathrm{O}_{5}$ & 0.12 & 0.16 & 0.05 & 0.5 & 0.09 & & 0.64 & 0.12 & 0.16 & 0.12 & 0.25 \\
\hline LOI & 2.51 & 2.66 & 1.91 & 2.04 & 1.2 & 0.71 & 0.2 & 0.45 & 0.25 & 0.6 & 0.2 \\
\hline $\begin{array}{l}\text { Total } \\
\text { (ppm) }\end{array}$ & 98.63 & $\begin{array}{l}100.8 \\
1\end{array}$ & 98.77 & 99.31 & 99.06 & $\begin{array}{l}100.4 \\
1\end{array}$ & 97.00 & 98.7 & 98.62 & 98.8 & 98.34 \\
\hline $\mathrm{Ba}$ & 48 & 35 & 49 & 47 & 440 & 2 & 38.3 & 61.5 & 208.7 & & 224.1 \\
\hline $\mathrm{Rb}$ & 294.3 & 351.1 & 286.9 & 298.3 & 306.8 & 340.1 & 18.4 & 5.59 & 5.96 & 0.4 & 2.79 \\
\hline $\mathrm{Sr}$ & 16.4 & 17.00 & 14.8 & 18.2 & 19.6 & 1.8 & 236 & 385 & 589.4 & 473 & 655 \\
\hline$Y$ & 46.00 & 94.7 & 40.7 & 31.7 & 39.1 & 31.2 & 17.5 & 22.3 & 9.09 & 15.1 & 5.82 \\
\hline $\mathrm{Zr}$ & & & & & & & 42.4 & 90.4 & 69.6 & 13.6 & 54.1 \\
\hline $\mathrm{Nb}$ & 186.4 & 183.7 & 335.1 & $\begin{array}{l}\text { \#\#\# } \\
\#\end{array}$ & 95.2 & 432.9 & 7.28 & 13.1 & 11.59 & 2.00 & 14.2 \\
\hline Th & 0.31 & 0.18 & 0.33 & 0.42 & 0.3 & 1.64 & 0.22 & 0.34 & 0.32 & 0.2 & 0.28 \\
\hline $\mathrm{Pb}$ & 2.76 & 2.56 & 2.31 & 1.1 & 4.49 & 3.05 & 0.06 & 0.07 & 0.06 & 0.07 & 0.09 \\
\hline $\mathrm{Cu}$ & 62 & 48 & 109 & 10 & 365 & 3 & 0.03 & 0.23 & 0.05 & $<0.05$ & 0.08 \\
\hline $\mathrm{Ni}$ & 47 & 33 & 41 & 46 & 28 & 1 & 0.56 & 0.92 & 0.8 & 0.42 & 0.18 \\
\hline V & & & & & & & 4.43 & 1.67 & 0.98 & 0.3 & 1.34 \\
\hline $\mathrm{Cr}$ & 48.00 & 48.00 & 512.00 & 84.00 & $\begin{array}{l}634.0 \\
0\end{array}$ & 17.00 & 57.1 & 34.2 & 19.5 & 53.1 & 21.7 \\
\hline $\mathrm{Hf}$ & 1.31 & 2.32 & 1.24 & 0.93 & 0.99 & 0.75 & 290 & 439 & 98.3 & 92.6 & 93.7 \\
\hline Sc & 97 & 78 & 89 & 79 & 61 & 12 & 175 & 192 & 76.3 & 45.6 & 48.7 \\
\hline Co & 269.00 & $\begin{array}{l}236.0 \\
0\end{array}$ & 550.00 & 18.00 & 48.00 & 4.00 & 78.9 & 82.1 & 54.1 & 59.2 & 31.4 \\
\hline$U$ & & & & & & & 9.64 & 3.56 & 6.54 & 3.00 & 7.88 \\
\hline La & 5.32 & 7.86 & 4.58 & 3.79 & 6.27 & 35.00 & 29.2 & 9.22 & 15.51 & 8.4 & 19.63 \\
\hline $\mathrm{Ce}$ & 11.78 & 16.52 & 10.67 & 8.73 & 13.97 & 55.94 & 25.2 & 5.49 & 9.32 & 8.7 & 13.07 \\
\hline $\mathrm{Nd}$ & 9.28 & 11.54 & 8.19 & 8.71 & 10.28 & 19.33 & 7.03 & 2.48 & 2.16 & 2.5 & 2.89 \\
\hline Sm & 2.52 & 2.79 & 2.26 & 2.59 & 2.6 & 2.17 & 1.84 & 0.86 & 0.87 & 0.81 & 0.99 \\
\hline $\mathrm{Eu}$ & 0.67 & 0.79 & 0.8 & 1.05 & 0.68 & 0.85 & 0.78 & 0.64 & 0.36 & 0.43 & 0.33 \\
\hline $\mathrm{Gd}$ & 2.7 & 3.09 & 2.65 & 3.27 & 3.13 & 1.66 & 1.81 & 2.28 & 0.91 & 1.6 & 0.99 \\
\hline $\mathrm{Tb}$ & & & & & & & 0.24 & 0.32 & 0.13 & 0.22 & 0.12 \\
\hline Dy & 3.14 & 3.22 & 2.88 & 3.5 & 3.44 & 0.41 & 7.33 & 1.47 & 6.4 & $>4$ & 3.5 \\
\hline Ho & 0.62 & 0.61 & 0.54 & 0.67 & 0.69 & & $\begin{array}{l}135.0 \\
0\end{array}$ & $\begin{array}{l}386.0 \\
0\end{array}$ & 807.00 & 2075 & 1309 \\
\hline $\mathrm{Er}$ & 1.78 & 1.84 & 1.59 & 1.86 & 2.11 & 0.16 & & & & & \\
\hline $\mathrm{Yb}$ & 1.95 & 1.96 & 1.61 & 1.77 & 2.25 & 0.15 & & & & & \\
\hline $\mathrm{Lu}$ & 0.26 & 0.26 & 0.19 & 0.22 & 0.32 & & & & & & \\
\hline $\mathrm{Zr}$ & & & & & & & & 90.4 & 69.6 & 13.6 & 54.1 \\
\hline \multirow{2}{*}{$\begin{array}{l}\text { Massif } \\
\text { Sampl } \\
\mathrm{e}\end{array}$} & \multicolumn{2}{|c|}{ SE Ghana } & $\begin{array}{l}\text { SE } \\
\text { Ghana }\end{array}$ & Agou & & Agou & & Agou & & Agou & \\
\hline & KB65 & KB67 & RT74 & A17 & Ag319 & A23 & A33 & ym13 & ym12 & A19 & A15 \\
\hline $\mathrm{SiO}_{2}$ & 53.6 & 48.6 & 50.1 & $\begin{array}{l}47.7 \\
1\end{array}$ & 49.13 & 51.59 & 50.78 & 53.9 & 45.41 & 56.55 & $\begin{array}{l}47.0 \\
4\end{array}$ \\
\hline $\mathrm{TiO}_{2}$ & 1.15 & 1.31 & 0.43 & 1.54 & 1.38 & 0.43 & 0.46 & 0.95 & 1.32 & 0.32 & 0.57 \\
\hline $\mathrm{Al}_{2} \mathrm{O}_{3}$ & 17.8 & 18.9 & 15.1 & $\begin{array}{l}15.6 \\
2\end{array}$ & 16.05 & 16.54 & 16.61 & 17.38 & 15.61 & 17.23 & $\begin{array}{l}20.1 \\
8\end{array}$ \\
\hline FeOt & 7.51 & 10.1 & 6.1 & 9.86 & 9.16 & 10.89 & 9.1 & 8.78 & 13.96 & 8.91 & $\begin{array}{l}10.3 \\
1\end{array}$ \\
\hline
\end{tabular}




\begin{tabular}{|c|c|c|c|c|c|c|c|c|c|c|c|}
\hline $\mathrm{MnO}$ & 0.13 & 0.22 & 0.14 & 0.17 & 0.16 & 0.19 & 0.15 & 0.15 & 0.21 & 0.2 & 0.13 \\
\hline $\mathrm{MgO}$ & 4.46 & 5.69 & 9.85 & 8.81 & 8.27 & 7.94 & 8.11 & 6.38 & 8.02 & 4.81 & 5.83 \\
\hline $\mathrm{CaO}$ & 7.7 & 8.7 & 10.4 & $\begin{array}{l}11.5 \\
7\end{array}$ & 11.18 & 9.83 & 11.09 & 9.11 & 13.82 & 6.56 & $\begin{array}{l}12.7 \\
7\end{array}$ \\
\hline $\mathrm{Na}_{2} \mathrm{O}$ & 4.36 & 3.31 & 2.86 & 2.92 & 3.28 & 3.23 & 3.19 & 3.16 & 2.23 & 4.31 & 1.75 \\
\hline $\mathrm{K}_{2} \mathrm{O}$ & 0.57 & 0.24 & 0.05 & 0.61 & 0.54 & 0.45 & 0.44 & 0.37 & 0.09 & 1.64 & 0.19 \\
\hline $\mathrm{P}_{2} \mathrm{O}_{5}$ & 0.25 & 0.34 & 0.03 & 0.27 & 0.24 & 0.05 & 0.07 & 0.19 & 0.13 & 0.03 & 0.06 \\
\hline LOI & 0.6 & 0.45 & 0.7 & 0.34 & 0.67 & & 0.04 & 0.27 & 0.13 & - & 0.31 \\
\hline $\begin{array}{l}\text { Total } \\
\text { (ppm) }\end{array}$ & 98.1 & 97.9 & 95.76 & $\begin{array}{l}99.4 \\
3\end{array}$ & $\begin{array}{l}100.0 \\
6\end{array}$ & $\begin{array}{l}101.1 \\
5\end{array}$ & $\begin{array}{l}100.0 \\
5\end{array}$ & $\begin{array}{l}100.6 \\
6\end{array}$ & 100.94 & $\begin{array}{l}100.5 \\
7\end{array}$ & $\begin{array}{l}99.1 \\
5\end{array}$ \\
\hline $\mathrm{Ba}$ & 318.00 & $\begin{array}{l}146.0 \\
0\end{array}$ & 13.02 & 51.6 & 67.3 & 72.1 & 40.9 & 37.5 & 14 & 69 & 28 \\
\hline $\mathrm{Rb}$ & 17.00 & 23.00 & & 1.9 & & & 0.6 & 1.00 & & & 0.2 \\
\hline $\mathrm{Sr}$ & 598 & 620 & 207.6 & $\begin{array}{l}284 . \\
6\end{array}$ & 288.3 & 303.6 & 295.1 & 315.2 & 96.2 & 236.8 & $\begin{array}{l}240 . \\
3\end{array}$ \\
\hline$Y$ & 10 & 19 & 19 & 25.4 & 23.2 & 17.5 & 14.8 & 22.9 & 54.8 & 10.4 & 12.9 \\
\hline $\mathrm{Zr}$ & 158 & 150 & 35 & 96.6 & 87.8 & 34.5 & 42.9 & 71.1 & 39.00 & 23.9 & 26.8 \\
\hline $\mathrm{Nb}$ & 28.00 & 32.00 & $<2.0$ & 13.2 & 10.8 & 2.2 & 0.9 & 2.3 & 2.1 & - & 1.3 \\
\hline Th & 0.25 & 0.17 & 0.08 & & & & & & & & \\
\hline $\mathrm{Pb}$ & 0.04 & 0.05 & 0.001 & & & & & & & & \\
\hline $\mathrm{Cu}$ & 0.09 & 0.08 & 0.06 & & & & & & & & \\
\hline $\mathrm{Ni}$ & 0.23 & 0.45 & 0.12 & $\begin{array}{l}175 . \\
6\end{array}$ & 171.8 & 43.1 & 61.4 & 64.7 & 198.6 & 13.00 & 26.9 \\
\hline V & 4.00 & 3.28 & 0.92 & & & & & & & & \\
\hline $\mathrm{Cr}$ & 22.00 & 29.2 & 41.07 & & & & & & & & \\
\hline $\mathrm{Hf}$ & 60.5 & 71.2 & 90.9 & 4.4 & & - & - & 3.7 & - & - & - \\
\hline $\mathrm{Sc}$ & 52.7 & 45.9 & 173.6 & & & & & & & & \\
\hline Co & 28.9 & 34.3 & 39.8 & & & & & & & & \\
\hline U & 11.8 & 6.42 & 1.71 & & & & & & & & \\
\hline La & 29.3 & 20.6 & 5.4 & 24.5 & & 6.65 & & 11.9 & & 2.72 & 6.45 \\
\hline $\mathrm{Ce}$ & 18.6 & 10.8 & 3.94 & 14.2 & & 5.12 & & 11.5 & & 1.72 & 5.63 \\
\hline $\mathrm{Nd}$ & 4.05 & 3.74 & 1.82 & 4.27 & & 1.78 & & 3.31 & & 0.61 & 1.99 \\
\hline $\mathrm{Sm}$ & 1.2 & 1.3 & 0.64 & 1.29 & & 0.51 & & 1.16 & & 0.32 & 0.67 \\
\hline Eu & 0.57 & 0.74 & 0.45 & 3.97 & & 2.00 & & 3.43 & & 0.88 & 1.95 \\
\hline $\mathrm{Gd}$ & 1.53 & 1.83 & 2.45 & 3.65 & & 2.15 & & 3.43 & & 1.03 & 1.75 \\
\hline $\mathrm{Tb}$ & 0.22 & 0.25 & 0.33 & & & & & & & & \\
\hline Dy & 2.78 & 2.38 & 1.33 & 22.6 & & 14.2 & & 20.00 & & 8.11 & 10.2 \\
\hline Ho & 278 & 86 & 207.5 & & & & & & & & \\
\hline $\mathrm{Yb}$ & & & & 0.94 & & 0.82 & & 1.04 & & 1.35 & 1.03 \\
\hline $\mathrm{Zr}$ & 158 & 150 & 35 & 96.6 & 87.8 & 34.5 & 42.9 & 71.1 & 39.00 & 23.9 & 26.8 \\
\hline & & & & & & & & & & & \\
\hline Massif & Agou & & Agou & & Agou & & Agou & & Agou & & \\
\hline Sample & Ag224 & ym26 & $\mathrm{A} 1$ & Ag262 & ym5 & $\mathrm{A} 2$ & A5b & A7 & A25 & $\mathrm{A} 5 \mathrm{a}$ & \\
\hline $\mathrm{SiO}_{2}$ & 53.4 & 63.45 & 52.42 & 53.07 & 53.5 & 45.68 & 45.13 & 46.85 & 46.25 & 64.57 & \\
\hline $\mathrm{TiO}_{2}$ & 0.76 & 0.62 & 0.42 & 0.46 & 1.08 & 1.26 & 1.06 & 1.35 & 1.09 & 0.37 & \\
\hline $\mathrm{Al}_{2} \mathrm{O}_{3}$ & 17.66 & 15.91 & 16.61 & 18.28 & 17.98 & 16.95 & 17.02 & 19.51 & 17.79 & 15.94 & \\
\hline $\mathrm{FeOt}$ & 11.42 & 8.04 & 10.12 & 11.27 & 11.9 & 15.79 & 15.24 & 12.97 & 14.05 & 5.54 & \\
\hline $\mathrm{MnO}$ & 0.15 & 0.14 & 0.17 & 0.19 & 0.2 & 0.2 & 0.22 & 0.25 & 0.2 & 0.1 & \\
\hline $\mathrm{MgO}$ & 5.69 & 2.91 & 4.67 & 5.28 & 4.2 & 5.89 & 6.15 & 3.79 & 6.3 & 1.79 & \\
\hline $\mathrm{CaO}$ & 9.92 & 5.74 & 8.71 & 9.54 & 8.37 & 9.6 & 10.43 & 8.69 & 9.33 & 5.98 & \\
\hline $\mathrm{Na}_{2} \mathrm{O}$ & 1.77 & 4.09 & 2.00 & 2.54 & 3.3 & 3.25 & 2.32 & 3.95 & 3.46 & 4.36 & \\
\hline
\end{tabular}




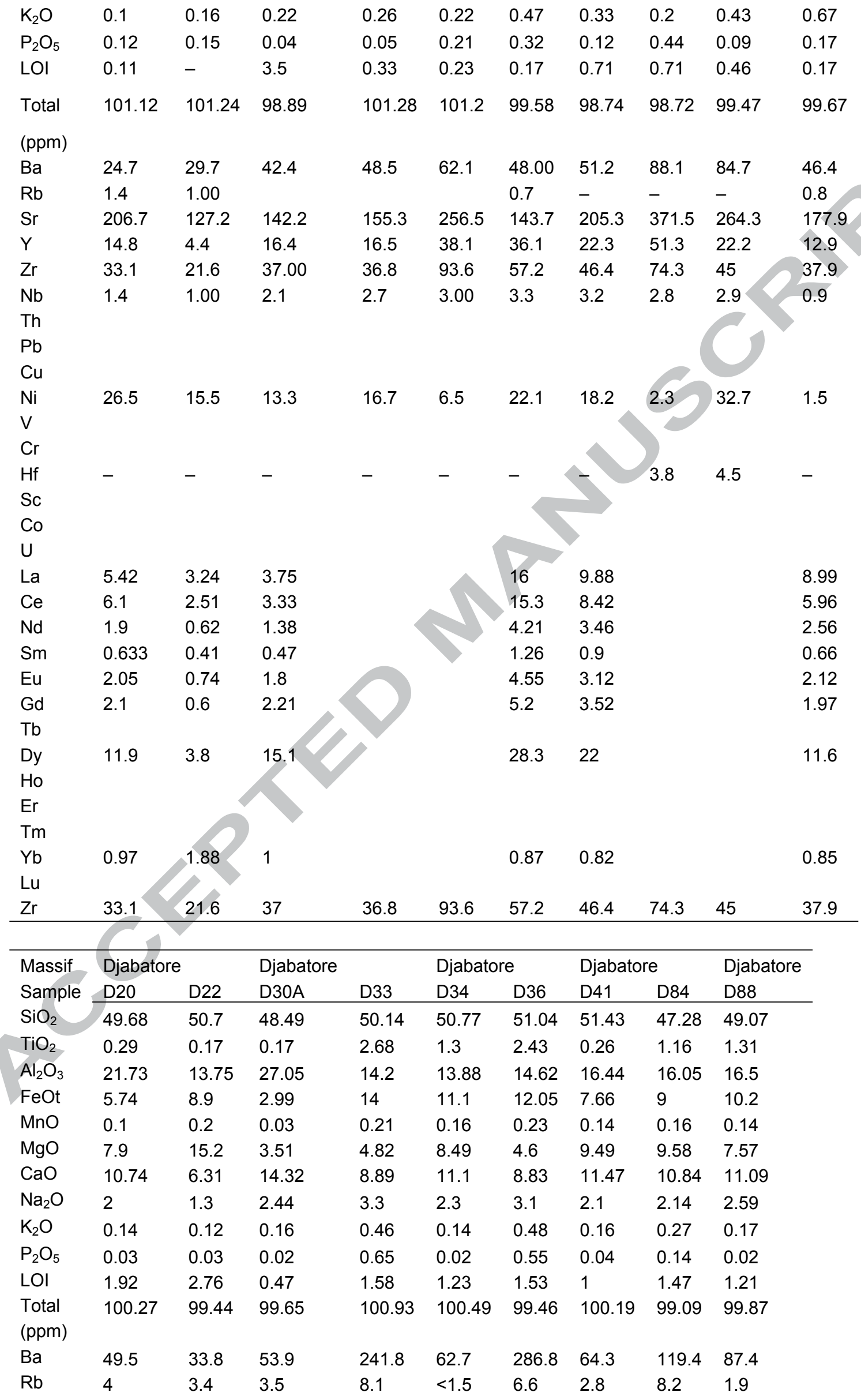




\begin{tabular}{|c|c|c|c|c|c|c|c|c|c|}
\hline $\mathrm{Sr}$ & 169.6 & 23.2 & 312 & 309.7 & 243.9 & 319.3 & 278.4 & 185.4 & 247.8 \\
\hline $\mathrm{Y}$ & 4.7 & 2.66 & 1.94 & 60 & 10.9 & 55.8 & 5.6 & 28.2 & 15 \\
\hline $\mathrm{Zr}$ & 17.8 & 19.2 & 17.2 & 265.2 & 22.4 & 259.4 & 18.8 & 87.2 & 24.2 \\
\hline $\mathrm{Nb}$ & 5.3 & 6.2 & 4.4 & 17.6 & 4.7 & 15.5 & 5.4 & 5.1 & 3.6 \\
\hline Th & $<3.0$ & $<3.0$ & $<3.0$ & $<3.0$ & $<3.0$ & $<3.0$ & $<3.0$ & $<3.0$ & $<3.0$ \\
\hline $\begin{array}{l}\mathrm{Pb} \\
\mathrm{Cu}\end{array}$ & 6.1 & 10.6 & 3.5 & 6.3 & 6.1 & 8.5 & 4.3 & 4 & 6.1 \\
\hline $\begin{array}{l}\mathrm{Ni} \\
\mathrm{V}\end{array}$ & 170 & 535 & 79.9 & 55 & 150 & 34.2 & 300 & 195 & 130 \\
\hline $\mathrm{Cr}$ & 350 & 375 & - & 70 & 300 & - & 360 & 345 & 290 \\
\hline $\begin{array}{l}\mathrm{Hf} \\
\text { Sc } \\
\text { Co }\end{array}$ & $<3.0$ & $<3.0$ & $<3.0$ & $<3.0$ & $<3.0$ & 6.9 & $<3.0$ & $<3.0$ & $<3.0$ \\
\hline U & $<3.0$ & $<3.0$ & $<3.0$ & $<3.0$ & $<3.0$ & $<3.0$ & $<3.0$ & $<3.0$ & $<3.0$ \\
\hline La & 1.7 & 1.3 & 1.25 & 20.5 & 0.8 & 16.6 & 1.19 & 3.73 & 1.04 \\
\hline $\mathrm{Ce}$ & 3.1 & 4.58 & 2.87 & 55.5 & 2 & 46.2 & 2.08 & 11.6 & 3.43 \\
\hline $\mathrm{Nd}$ & 1.5 & 3.2 & 1.4 & 35.6 & 2.4 & 31.2 & 2.36 & 9.34 & 3.72 \\
\hline Sm & 0.4 & 0.691 & 0.374 & 9.17 & 0.9 & 8.24 & 0.94 & 3.1 & 1.31 \\
\hline Eu & 0.4 & 0.401 & 0.432 & 3.15 & 0.5 & 2.72 & 0.43 & 1.23 & 0.97 \\
\hline $\mathrm{Gd}$ & 0.5 & 0.596 & 0.445 & 10.7 & 1.3 & 9.65 & 0.95 & 4.14 & 1.97 \\
\hline $\mathrm{Tb}$ & & - & - & - & 0.2 & & & & \\
\hline $\begin{array}{l}\text { Dy } \\
\text { Ho }\end{array}$ & 0.4 & 0.506 & 0.352 & 9.93 & $\begin{array}{l}1.5 \\
0.3\end{array}$ & 9.06 & 0.94 & & 5.92 \\
\hline $\mathrm{Er}$ & 0.3 & 0.297 & 0.205 & 5.79 & 0.8 & 5.34 & 0.29 & & 3.6 \\
\hline Tm & & - & - & 0 & & 0 & & 0 & 0 \\
\hline $\mathrm{Yb}$ & 0.2 & 0.311 & 0.186 & 5.52 & 0.7 & 5.05 & 0.48 & & 3.36 \\
\hline Lu & & - & - & 0.84 & & 0.78 & & 0.4 & 0.22 \\
\hline $\mathrm{Zr}$ & 19.2 & 17.2 & 265.2 & 22.4 & 259.4 & 18.8 & 87.2 & 24.2 & 7.2 \\
\hline
\end{tabular}

